\title{
Lodgepole pine and trembling aspen mixedwoods: Growth and yield within 22 to 39 year old pine plantations of northern interior British Columbia.
}

\author{
by George Harper ${ }^{1}$
}

\begin{abstract}
Six lodgepole pine plantations located in the Sub Boreal Spruce (SBS) biogeoclimatic zone of northern interior British Columbia were chosen to study the impacts of aspen competition on the growth and yield of lodgepole pine. The six sites from four different zonal variants ( $\mathrm{dw} 2, \mathrm{dw} 3, \mathrm{dk} 1$ and $\mathrm{mc}$ ) ranged in age from 22 to 39 years. Site preparation treatments occurred on all sites: drag scarification, disking, or a broadcast burn post clear-cut logging. Four of the sites received at least one operational brushing treatment for aspen (chemical or manual). At each site, 30 pine trees $(\mathrm{CP})$ were selected as plot centres to represent the observed range of aspen competition. A series of nested plots up to $7.98 \mathrm{~m}$ radius was used to evaluate effects of $\%$ pine composition on stand density and stand volume using linear and non-linear models. At five of the six sites total volume was unchanged across the range of pine composition. The growth interaction between aspen and pine was found to be a linear relationship of competitive reduction where pine volume, basal area and merchantable volume was highly sensitive to any increase in aspen density or composition.
\end{abstract}

Keywords: Lodgepole pine, aspen, boreal mixedwoods, growth and yield, merchantable volume, basal area, competition.

\section{RÉSUMÉ}

Six plantations de pin lodgepole situées dans le sud de la zone biogéoclimatique de lépinette subboréale (SBS) dans la région nord de l'intérieur de la Colombie-Britannique ont été choisies pour étudier les effets de la compétition par le tremble sur la croissance et le rendement du pin lodgepole. Les six plantations établies dans quatre variantes zonales (dw2, dw3, dk1 et mc2) étaient âgées de 22 à 39 ans. Des travaux de préparation du site ont été réalisés sur tous les sites : scarifiage par traînage et au moyen de disques ou encore par brûlage contrôlé après coupe à blanc. Quatre des six plantations ont fait l'objet d'au moins un traitement de débroussaillage (chimique ou manuel) afin de contrôler le tremble. Dans chaque plantation, 30 pins (CP) ont été choisis comme centres de parcelles-échantillons destinées à étudier l'importance de la compétition par le tremble. Une série de parcelles regroupées jusquà un rayon de 7,98 $\mathrm{m}$ a été utilisée pour évaluer les effets du pourcentage de la composition en pin sur la densité et le volume du peuplement en se servant de modèles linéaires et non linéaires. Pour cinq des six plantations, le volume total est demeuré inchangé, peu importe la composition en pin. L'effet de l'interaction entre le tremble et le pin sur la croissance se traduit par une relation linéaire où le volume du pin, sa surface terrière et son volume marchand diminuaient significativement avec tout accroissement de la densité ou de la composition en tremble.

Mots clés : pin lodgepole, tremble, forêts boréales mixtes, croissance et rendement, volume marchand, surface terrière, compétition

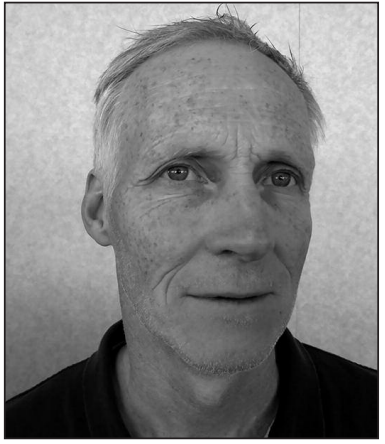

George Harper

\section{Introduction}

Mixed stands of lodgepole pine (Pinus contorta Dougl.) and trembling aspen (Populus tremuloides Michx.) are common in the Sub-Boreal Spruce biogeoclimatic zone (SBS) of interior British Columbia (Meidinger and Pojar 1991). Both species have evolved to regenerate at high densities after natural disturbances such as fire and both have rapid juvenile growth rates. However, lodgepole pine and other conifers such as white spruce (Picea glauca Moench) can become overtopped and suppressed due to aspen's superior early height growth. Aspen root sucker densities are commonly in excess of 20000 trees per hectare (tph) allowing aspen to quickly dominate young stand development influencing understorey growing conditions through impacts to light, air and soil temperature, soil moisture and nutrient conditions (Frey et al. 2003, McKinnon and Kayahara 2003, Voicu and Comeau 2006).

Forest management in the SBS zone has historically involved clear-cut logging and some type of site preparation followed by planting of conifers, typically lodgepole pine.

\footnotetext{
${ }^{1}$ Resource Practices Branch, B.C. Ministry of Forests, Lands and Natural Resource Operations, PO BOX 9513 Stn Prov Govt, Victoria, BC, Canada V8W 9C2 email: George.Harper@gov.bc.ca
} 
Vigorous aspen regeneration found either in clumps or even distributions have resulted in many pine plantations receiving aspen brushing treatments (herbicide and manual) to address the impacts to conifer survival and growth (DeLong 2007, Newsome et al. 2008). Under the Forest and Range Practices Act (FRPA) of BC (BC MFLNRO 2015), forest licensees are required to establish healthy well-spaced plantations free from deleterious competition. This requirement ensures newly established stands grow in accordance with timber supply expectations. Acceptance of broadleaf species can be problematic and management of broadleaf-conifer mixedwoods remains a complex issue, confounded by policy, economics, historic forestry practices and timber supply expectations (Sheldan and Snetsinger 2008). The presence of aspen contributes valuable broadleaf tree and stand attributes that maintain and enhance SBS zone forest health, ecology, wildlife communities, forest biodiversity and resilience (St. Clair et al. 2013, Harper and Roach 2014).

The need to quantify lodgepole pine (hereafter referred to as pine) growth response to changes in aspen competition has been of interest since at least the early 1990s (Navratil et al. 1990, DeLong and Tanner 1996, Newsome 1997). Much research has focused on understanding and predicting the response of pine to the range of light environments within aspen-pine mixedwoods (Landhausser and Lieffers 2001, Claveau et al. 2005, Harper et al. 2009). Research has shown pine height and diameter growth increase in a linear fashion with increases in light availability and, diameter growth has been found to respond to reductions in competition levels more quickly than height growth (MacIsaac and Navratil 1996, Wright et al. 1998, Coates 2000, Newsome et al. 2003). This is apparently due to the higher priority of height growth over diameter growth (Chen et al. 1996, Williams et al. 1999, Claveau et al. 2002). Consequently, lower competition levels have been found to influence diameter increment more than height increment (Newsome et al. 2003, Strong and Sidhu 2005, Newsome et al. 2010). Published studies from seven SBS sites indicate a positive pine diameter growth response to aspen removal treatments (Lange et al. 2004, DeLong 2007, Newsome et al. 2008, Harper et al. 2009). Height growth response to aspen removal was noted as positive in five of the seven sites examined by Newsome et al. 2004, 2006a, 2006b, 2008. Pine growth response has been found more variable in southern BC where drier climatic conditions may impact aspen productivity (Heineman et al. 2010). From a total of 13 study locations in southern interior $\mathrm{BC}$, pine diameter growth response to brushing treatments was noted as positive on eight sites found in the Interior Douglas-fir (IDF), Interior Cedar Hemlock (ICH) and Montane Spruce (MS) biogeoclimatic zones (Simard et al. 2001, Prasad 2002, Simard et al. 2005, Heineman et al. 2010). Pine height response results were variable, noted as positive, negative or not significant depending on the site.

Thirty-seven publications were reviewed that summarize pine and aspen competition studies from $21 \mathrm{BC}$ research sites. Most of this information documents vegetation control treatment response of young plantations less than 24 years of age, prior to canopy closure. As a result, there is a lack of information on the stand exclusion or post canopy closure phase. Stand level information is required to examine the growth and yield consequences of increasing aspen composition within managed pine plantations. Timber supply planning relies on accurate yield predictions to determine annual harvest levels. Stand yield prediction has been shown to be directly linked to the effectiveness of silviculture practices such as vegetation management that assume a certain level of brush removal and competition abatement (South and Miller 2007, Harper et al. 2008, Cortini et al. 2010).

This paper presents the results of a retrospective study of interspecific competition between lodgepole pine and trembling aspen found in operationally established, closed canopy pine plantations. The approach taken was similar to that of Harper et al. (2009) where the objectives were to collect tree and stand level data to allow prediction of pine growth relative to neighbourhood aspen competition; and, to describe the impact of aspen composition on pine stand total and merchantable volume attributes.

\section{Methods}

Six pine plantation sites were selected during the summers of 2013 and 2014, all located within the SBS zone of the northern interior of British Columbia (Table 1). The sites are: Tamarack Lake, located near Bednesti (BE); Dog Creek (DG) and Pitka Creek (PI), both located south of Fort St. James; Loon Lake (LL), located south of Pinchi Lake; Chehishic Creek (CC) and Tako Creek (TC), both located north of the Blackwater River, northwest of Quesnel (Fig. 1). The sites are located in one of four SBS subzones (dw2, dw3, dk1 and mc2) characterized through zonal plant associations and relative moisture availability (Meidinger and Pojar 1991). The continental climate of the central BC interior is characterized by severe snowy winters and warm, moist but short summers with a mean annual temperature of $1.7^{\circ} \mathrm{C}-5^{\circ} \mathrm{C}$ and a mean annual precipitation of $415 \mathrm{~mm}-1650 \mathrm{~mm}$ of which up to $50 \%$ is snowfall. The sites ranged in age from $22-39$ years since planting of lodgepole pine and all were found in an advanced state of early stand development, having previously been declared "free growing" lodgepole pine plantations (BC MFLNRO 2013). Free growing (FG) is a term used to describe the legal obligation to establish a stand of healthy crop trees free from pests, disease and vegetation competition. All sites were selected from the available population of FG cut-blocks located during an extensive office and field survey. Due to the recent mountain pine beetle (MPB) epidemic (BC MFLNRO 2012), the population of healthy pine stands was limited. Candidate sites were required to be accessible by road, stocked with planted pine with little evidence of MPB attack or disease and to contain significant areas of aspen.

Records indicated clear-cut harvesting, site preparation and planting occurred at each of the six sites. All sites received some sort of site preparation, either drag scarification (BE, LL, CC), disking (LL, PI, TC), or a broadcast burn (DG). Lodgepole pine seedlings were subsequently planted at all six sites. Herbicide or manual brushing treatments were prescribed at four of the six pine plantations to control competing vegetation (primarily aspen). Glyphosate herbicide was used as part of a "hack and squirt" brushing treatment at the $\mathrm{BE}$ site. A manual brushing treatment also occurred at $\mathrm{BE}$ (eight years after herbicide treatment) and at the LL site (three years post-planting). Aerial broadcast glyphosate application occurred at the TC and CC sites six and three years respectively after planting. Records indicated 1300 trees per hectare (tph) were planted at BE, 1500 tph at DG, 1200 tph at PI, and 
Table 1. Site location and silviculture history information.

\begin{tabular}{|c|c|c|c|}
\hline $\begin{array}{l}\text { Site name } \\
\text { BEC variant }^{\mathrm{a}}\end{array}$ & $\begin{array}{l}\text { Lat. } \\
\text { Long. }\end{array}$ & $\begin{array}{l}\text { Avg. slope / Soils } \\
\text { Elevation }\end{array}$ & Silviculture history \\
\hline $\begin{array}{l}\text { Tamarack } \\
\text { Lake (BE) } \\
\text { SBS dw3 }\end{array}$ & $\begin{array}{c}535230 \mathrm{~N} \\
1231912 \mathrm{~W}\end{array}$ & $\begin{array}{l}10 \% \text { / Silt Loam } \\
\quad 840 \mathrm{~m}\end{array}$ & $\begin{array}{l}\text { Clearcut } 1983 \text { ( } 68 \text { ha), site prepared } 1984 \text { (drag scarified), herbicide } 1985 \\
\left.\text { (hack } \boldsymbol{n} \text { squirt with } \text { glyphosate }{ }^{\mathrm{b}}\right) \text {, planted } 1986\left(2+0 \mathrm{BR}^{\mathrm{c}} \text { lodgepole pine), }\right. \\
\text { manual brushing 1993, declared Free to Grow } 1996 .\end{array}$ \\
\hline $\begin{array}{l}\text { Dog Creek (DG) } \\
\text { SBS dw3 }\end{array}$ & $\begin{array}{l}54180 \mathrm{~N} \\
12420 \mathrm{~W}\end{array}$ & $\begin{array}{l}3 \% \text { / Sandy Loam } \\
\quad 860 \mathrm{~m}\end{array}$ & $\begin{array}{l}\text { Clearcut } 1971 \text { ( } 39 \text { ha), broadcast burnt 1974, planted } 1976 \text { (PSB }{ }^{\mathrm{d}} 1+0 \\
\text { lodgepole pine), declared Free to Grow } 1992 \text {. }\end{array}$ \\
\hline $\begin{array}{l}\text { Loon Lake (LL) } \\
\text { SBS dk1 }\end{array}$ & $\begin{array}{c}543240 \mathrm{~N} \\
1241912 \mathrm{~W}\end{array}$ & $\begin{array}{l}8 \% \text { / Silt Loam } \\
\quad 800 \mathrm{~m}\end{array}$ & $\begin{array}{l}\text { Clearcut } 1984 \text { ( } 56 \text { ha), site prepared } 1985 \text { (chain drag) \& } 1991 \text { (disked), } \\
\text { planted } 1992 \text { ( } 2+0 \text { BR lodgepole pine), manually brushed 1995, declared } \\
\text { Free to Grow } 2000 .\end{array}$ \\
\hline $\begin{array}{l}\text { Pitka Creek (PI) } \\
\text { SBS mc2 }\end{array}$ & $\begin{array}{r}541825 \mathrm{~N} \\
1242249 \mathrm{~W}\end{array}$ & $\begin{array}{l}2 \% \text { / Silt Loam } \\
\quad 875 \mathrm{~m}\end{array}$ & $\begin{array}{l}\text { Clearcut } 1985 \text { ( } 170 \text { ha), site prepared (disked) 1987, planted } 1988 \text { (PSB } 1+0 \\
313 \text { lodgepole pine), declared Free to Grow } 2007 \text {. }\end{array}$ \\
\hline $\begin{array}{l}\text { Tako Creek (TC) } \\
\text { SBS dw2 }\end{array}$ & $\begin{array}{l}531840 \mathrm{~N} \\
123230 \mathrm{~W}\end{array}$ & $\begin{array}{l}2 \% \text { / Silt Loam } \\
\quad 770 \mathrm{~m}\end{array}$ & $\begin{array}{l}\text { Clearcut } 1989 \text { ( } 69 \text { ha), site prepared } 1989 \text { (disked), planted } 1990 \text { (PSB } \\
\text { lodgepole pine), herbicide } 1996 \text { (aerial glyphosate), declared } \\
\text { Free to Grow 2008. }\end{array}$ \\
\hline $\begin{array}{l}\text { Chehishic Creek } \\
\text { (CC) SBS dw3 }\end{array}$ & $\begin{array}{c}53300 \mathrm{~N} \\
123210 \mathrm{~W}\end{array}$ & $\begin{array}{l}9 \% \text { / Silt Loam } \\
\quad 860 \mathrm{~m}\end{array}$ & $\begin{array}{l}\text { Clearcut } 1986 \text { ( } 77 \text { ha), site prepared } 1986 \text { (chain drag) \& } 1991 \text { (disked), } \\
\text { planted } 1992 \text { (PSB 1+ } 0 \text { 313A lodgepole pine), herbicide } 1995 \text { (aerial } \\
\text { glyphosate), declared Free to Grow } 2008 .\end{array}$ \\
\hline
\end{tabular}

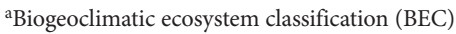

${ }^{\mathrm{b}}$ Glyphosate is the active ingredient of the herbicide Roundup or Vision used during operational treatments

${ }^{\mathrm{c}} \mathrm{BR}=$ bare root seedlings

${ }^{\mathrm{d}} \mathrm{PSB}=$ poly-styroblock nursery containers

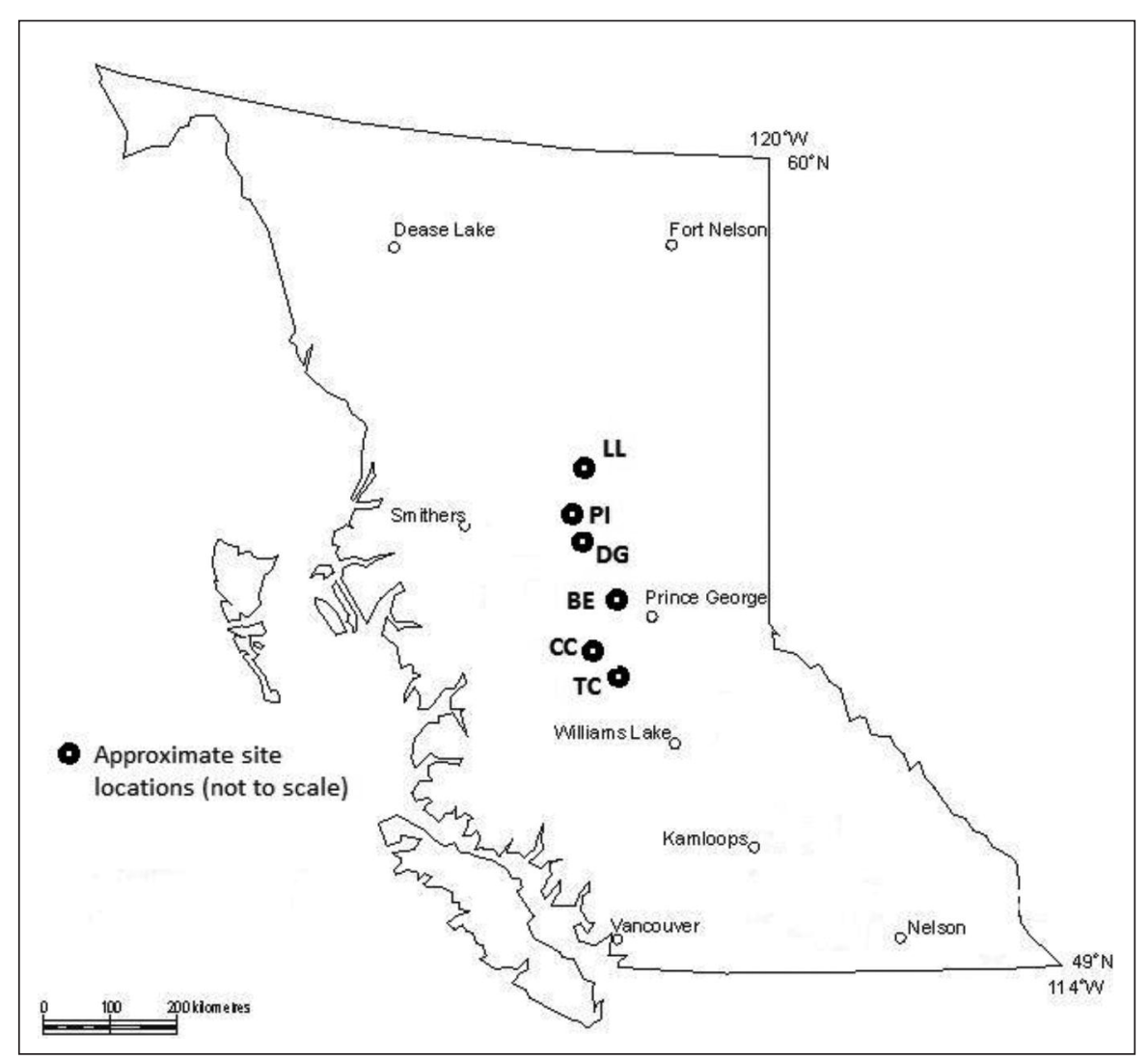

Fig. 1. General site locations shown for six Sub-Boreal Spruce zone (SBS) pine plantations found in northern British Columbia. Site coordinates and silviculture history found in Table 1.
1400 tph at TC. At the LL and CC sites, natural pine regeneration was promoted using chain drag site preparation. Subsequent planting densities at these two sites were lower, $1000 \mathrm{tph}$ and $1100 \mathrm{tph}$ respectively. During 2013 and 2014 the six sites were assessed at least 18 years post-brushing and six years post-FG declaration. Aspen was found to occupy significant area within these six pine plantations. It was difficult to determine with certainty the precise amount and distribution of aspen earlier in plantation establishment. However, site history records, maps and photos provided survey evidence that aspen was and continues to be a key inventory component.

At each site, 30 pine-centred plots were established using regression sampling (Demaerschalk and Kozak 1974). Pine were selected across the observed range of aspen competition using five simple subjective categories of aspen presence (no aspen competition, slight, moderate, heavy and extreme) with six pine selected for each category. Centre pine $(\mathrm{CP})$ selection included 
suppressed and co-dominant as well as dominant planted pine trees. The $30 \mathrm{CPs}$ at each site were selected on a measured grid that ensured a minimum inter-plot distance of 20 m. At each CP, a series of variable radius subplots were established following the procedure used in Zhao et al. (2004) and Filipescu and Comeau (2007). All trees were tallied (alive and dead) in a series of concentric circular subplots such that a $3.99 \mathrm{~m}$ radius plot $(0.005 \mathrm{ha})$ was used for all trees with a diameter at breast height $(\mathrm{DBH}) \leq 8 \mathrm{~cm}$, a $5.64 \mathrm{~m}$ radius plot (0.01 ha) for trees $>8 \mathrm{~cm}$ but $\leq 16 \mathrm{~cm} \mathrm{DBH}$, and a $7.98 \mathrm{~m}$ radius plot (0.02 ha) for all trees $>16 \mathrm{~cm} \mathrm{DBH}$. The $\mathrm{DBH}$, total height, height increments for the last two growing seasons, crown radius (E, W, N, S), height to lowest live branch (bottom of the live crown) and tree crown class (Walmsley et al. 1980) were assessed on the CP and the nearest six neighbourhood trees ( $>1.3 \mathrm{~m}$ in height), including their distance and azimuth (nearest neighbours included in sub-plot data). On a subset of the CPs ( 10 of the 30 ), selected across the aspen competition range of each site, $\mathrm{DBH}$ was measured on all trees (alive and dead) in all subplots and heights on a representative sample.

This regression sampling approach provided the stand and tree level data to allow exploration of stand density and productivity within the range of pine and aspen mixtures found at each site. The objective of the analysis was to fit linear and non-linear equations describing the site growth and yield relationships of volume, basal area and density, focusing on forest productivity and tree species interrelationships (Pretzsch 2009). Data analysis was completed using SAS version 9.3 (SAS Institute Inc. 2010). Statistical significance was based on $\mathrm{P}<0.05$. Linear and non-linear regression analysis followed that of Sit and Poulin-Costello (1994). Linear and nonlinear regression models were used to test for significant

Table 2. Parameters for equation \#1 from Temesgen and Gadow (2004). Model used is a modified Weibull- type function where height $\mathrm{H}=1.3+a\left[1-\mathrm{ebDBH} \mathrm{H}^{c}\right]$. All model $P$ values $<0.0001$.

\begin{tabular}{lccccccc}
\hline Site & Group & $\boldsymbol{n}$ & $\mathbf{a}$ & $\mathbf{b}$ & $\mathbf{c}$ & $\mathbf{R}^{2}{ }_{\text {adj }}$ & RMSE $^{\mathbf{d}}$ \\
\hline Tamarack Lake (BE) & $1^{\mathrm{a}}$ & 28 & 16.013 & 0.142 & 0.919 & 0.92 & 1.207 \\
& $2^{\mathrm{b}}$ & 57 & 12.917 & 0.166 & 1.006 & 0.93 & 1.163 \\
& & & & & & & \\
Dog Creek(DG) & 1 & 29 & 21.355 & 0.058 & 1.231 & 0.79 & 1.509 \\
& 2 & 50 & 16.078 & 0.038 & 1.559 & 0.93 & 1.042 \\
& $3^{\mathrm{c}}$ & 9 & 2.853 & 0.117 & 2.711 & 0.57 & 0.721 \\
Loon Lake (LL) & 1 & 40 & 14.856 & 0.111 & 1.052 & 0.82 & 1.011 \\
& 2 & 49 & 9.443 & 0.085 & 0.954 & 0.89 & 1.080 \\
Pitka Creek (PI) & 1 & 45 & 16.483 & 0.078 & 1.246 & 0.90 & 1.276 \\
& 2 & 41 & 14.246 & 0.121 & 1.615 & 0.91 & 1.422 \\
Tako Creek (TC) & 1 & 52 & 17.369 & 0.081 & 1.213 & 0.91 & 1.298 \\
& 2 & 91 & 13.106 & 0.078 & 1.209 & 0.92 & 1.505 \\
Chehishic Creek (CC) & 1 & 44 & 12.821 & 0.159 & 0.980 & 0.93 & 0.894 \\
& 2 & 82 & 12.12 & 0.141 & 1.021 & 0.95 & 1.146 \\
& & & & & & & \\
\hline
\end{tabular}

aBroadleaf species (aspen, cottonwood and birch)

${ }^{b}$ Lodgepole pine (and balsam fir and spruce $>8 \mathrm{~cm} \mathrm{DBH}$ )

'Understorey spruce and balsam fir $(<8 \mathrm{~cm} \mathrm{DBH})$

${ }^{\mathrm{d}}$ Root mean squared error change across a range of independent variables. Adjusted $\mathrm{R}^{2}=1-[(\mathrm{n}-1) /(\mathrm{n}-\mathrm{p})] \mathrm{SS}_{\mathrm{E}} / \mathrm{SST}_{\mathrm{C}}\left(\mathrm{R}_{\text {adj }}^{2}\right)$ was calculated for all equations (Cornell and Berger 1987). Residual plots were assessed visually for each fitted equation and models were evaluated using root mean squared error (RMSE) and $\mathrm{R}_{\text {adj }}^{2}$. A multiple regression approach (Chen 1997) was used to determine if the data from individual sites could be pooled (i.e., besides the continuous regressor, effects were added to account for site and the site-by-regressor interaction). Nonlinear models were linearized for the pooled multiple-site regression test (Proc Mixed), otherwise the non-linearized results are presented (Proc NLIN). Caution was used in interpreting regression statistics since statistical significance was considered to be evidence of a response; however, the inference was not considered conclusive at the site level (Neter et al. 1990).

Stem volume for each conifer or deciduous tree was calculated using Kozak (1988) taper equations. Heights not measured were predicted from the height-DBH relationship of those measured (by site) using the modified Weibull type function of Temesgen and Gadow (2004) based on Yang et al. (1978):

\section{(1) $\mathrm{H}=1.3+a\left(1-\mathrm{e} b \mathrm{DBH}^{c}\right)$}

Where $\mathrm{H}=$ tree height. The results of fitting equation (1), used to calculate missing tree heights, are presented in Table 2 where separate parameters are provided for broadleaf and pine stems. This prediction exercise did not use model linearization or multiple-site regression. These parameters were used to calculate heights for the 10 growth and yield (GY) plots per site, where all stems were measured for DBH but not all heights. The resulting dataset was used to compile tree and stand volumes, basal area, merchantable volumes, and stand and stock tables for each plot by species. Stand level plot summaries by tree species for total and merchantable volume included tallies by $5-\mathrm{cm} \mathrm{DBH}$ classes (minimum $30 \mathrm{~cm}$ stump and 5$\mathrm{cm} \mathrm{DBH).}$

\section{Results}

Within the 30 CP plots assessed at each of the six sites, a range of aspen-pine mixedwood stand conditions were purposely chosen with aspen density ranging from 0 to 15500 tph and pine from 100 to 8900 tph (Table 3). Pine was the primary conifer component with scattered individuals of understorey white spruce (Picea glauca [Moench] Voss $\mathrm{x}$ engelmannii Parry ex Engelm.), subalpine fir (Abies lasiocarpa [Hook.] Nutt.) and interior Douglas-fir (Pseudotsuga menziesii [Mirb.] Franco). Also, in addition to aspen, there were minor occurrences of paper birch (Betula papyrifera Marsh.) and black cotton- 
Table 3. Stand component densities and dominant height (top height) statistics by site. Densities calculated from tally plots $(n=30)$ and top heights from growth and yield plots $(n=10)$. Top height was defined as the mean height of the 100 largest DBH trees per hectare (tph).

\begin{tabular}{|c|c|c|c|c|c|c|}
\hline Site & $\begin{array}{l}\text { Aspen density } \\
(\text { tph })\end{array}$ & $\begin{array}{c}\text { Pine density } \\
(\text { tph })\end{array}$ & $\begin{array}{l}\text { Understorey } \\
\text { density (tph) }\end{array}$ & $\begin{array}{l}\text { Total density } \\
\text { (tph) }\end{array}$ & $\begin{array}{l}\text { Aspen top } \\
\text { height (m) }\end{array}$ & $\begin{array}{c}\text { Pine top } \\
\text { height }(\mathbf{m})\end{array}$ \\
\hline Tamarack Lake (BE) & $\begin{array}{c}4465 \pm 4761^{\mathrm{a}} \\
0-15500^{\mathrm{b}}\end{array}$ & $\begin{array}{c}1760 \pm 1382 \\
100-4750\end{array}$ & $\begin{array}{c}482 \pm 714 \\
0-3000\end{array}$ & $\begin{array}{c}6760 \pm 4465 \\
1350-18100\end{array}$ & $\begin{array}{l}11.2 \pm 1.5 \\
8.8-13.1\end{array}$ & $\begin{array}{c}12.1 \pm 0.97 \\
9.7-13.1\end{array}$ \\
\hline Dog Creek (DG) & $\begin{array}{c}3998 \pm 3589 \\
0-12200\end{array}$ & $\begin{array}{c}1670 \pm 395 \\
1000-2650\end{array}$ & $\begin{array}{c}1130 \pm 852 \\
0-3100\end{array}$ & $\begin{array}{c}6988 \pm 3377 \\
2800-14500\end{array}$ & $\begin{array}{c}15.6 \pm 1.6 \\
11.8-17.1\end{array}$ & $\begin{array}{c}14.4 \pm 1.1 \\
13.0-16.8\end{array}$ \\
\hline Loon Lake (LL) & $\begin{array}{c}5652 \pm 4111 \\
0-15500\end{array}$ & $\begin{array}{c}3375 \pm 2389 \\
400-8900\end{array}$ & $\begin{array}{c}73 \pm 131 \\
0-500\end{array}$ & $\begin{array}{c}9160 \pm 3516 \\
3550-15800\end{array}$ & $\begin{array}{l}10.1 \pm 2.0 \\
7.6-12.6\end{array}$ & $\begin{array}{c}10.1 \pm 0.58 \\
9.4-11.0\end{array}$ \\
\hline Pitka Creek (PI) & $\begin{array}{c}4080 \pm 3557 \\
0-14500\end{array}$ & $\begin{array}{l}1678 \pm 745 \\
400-3800\end{array}$ & $\begin{array}{c}115 \pm 149 \\
0-600\end{array}$ & $\begin{array}{c}5913 \pm 3196 \\
1750-15100\end{array}$ & $\begin{array}{l}14.3 \pm 0.85 \\
12.4-15.1\end{array}$ & $\begin{array}{l}10.2 \pm 2.8 \\
3.1-12.8\end{array}$ \\
\hline Tako Creek (TC) & $\begin{array}{c}1590 \pm 1238 \\
0-4650\end{array}$ & $\begin{array}{l}1590 \pm 425 \\
800-2550\end{array}$ & $\begin{array}{c}1305 \pm 1142 \\
0-4450\end{array}$ & $\begin{array}{l}4737 \pm 1832 \\
1600-9600\end{array}$ & $\begin{array}{c}13.3 \pm 1.7 \\
10.4-15.7\end{array}$ & $\begin{array}{l}11.7 \pm 1.5 \\
8.6-13.3\end{array}$ \\
\hline Chehishic Creek (CC) & $\begin{array}{c}1983 \pm 1636 \\
0-5800\end{array}$ & $\begin{array}{l}2230 \pm 983 \\
950-4800\end{array}$ & $\begin{array}{c}440 \pm 432 \\
0-1600\end{array}$ & $\begin{array}{l}4690 \pm 1772 \\
2000-9100\end{array}$ & $\begin{array}{l}11.1 \pm 0.63 \\
10.1-12.0\end{array}$ & $\begin{array}{c}11.1 \pm 0.75 \\
9.6-12.5\end{array}$ \\
\hline
\end{tabular}

${ }^{a}$ Mean and standard deviation

${ }^{b}$ Range

Table 4. Central pine (CP) growth parameter statistics summarized by site $(n=30)$.

\begin{tabular}{|c|c|c|c|c|c|c|}
\hline Site & $\begin{array}{l}\mathrm{DBH} \\
(\mathrm{cm})\end{array}$ & $\begin{array}{l}\text { Height } \\
(\mathrm{m})^{\mathrm{a}}\end{array}$ & HDR $^{b}$ & $\begin{array}{l}\text { Crown radius } \\
(\mathrm{cm})\end{array}$ & $\begin{array}{l}\text { Height to } \\
\text { base of } \\
\text { crown }(\mathrm{cm})\end{array}$ & $\begin{array}{c}\text { Planted } \\
\text { pine age }^{\mathrm{c}}\end{array}$ \\
\hline Tamarack Lake (BE) & $\begin{array}{l}14.3 \pm 2.8^{\mathrm{d}} \\
8.5-20.4^{\mathrm{e}}\end{array}$ & $\begin{array}{l}12.46 \pm 1.54 \\
9.20-15.90\end{array}$ & $\begin{array}{c}89.7 \pm 15.8 \\
72.6-148.2\end{array}$ & $\begin{array}{l}151.8 \pm 34.4 \\
61.5-227.3\end{array}$ & $\begin{array}{l}486 \pm 157 \\
150-750\end{array}$ & $\begin{array}{c}30 \\
-\end{array}$ \\
\hline Dog Creek (DG) & $\begin{array}{l}14.3 \pm 3.7 \\
5.6-21.8\end{array}$ & $\begin{array}{l}15.32 \pm 2.38 \\
8.50-18.10\end{array}$ & $\begin{array}{l}110.8 \pm 18.6 \\
75.9-172.0\end{array}$ & $\begin{array}{c}107.0 \pm 29.1 \\
51-170.3\end{array}$ & $\begin{array}{c}796 \pm 232.4 \\
220-1070\end{array}$ & $\begin{array}{l}39 \\
-\end{array}$ \\
\hline Loon Lake (LL) & $\begin{array}{l}11.4 \pm 3.0 \\
4.1-15.8\end{array}$ & $\begin{array}{c}9.85 \pm 1.78 \\
5.50-12.70\end{array}$ & $\begin{array}{c}90.7 \pm 19.5 \\
68.3-158.5\end{array}$ & $\begin{array}{l}130.4 \pm 37.1 \\
50.8-199.3\end{array}$ & $\begin{array}{c}376 \pm 130.7 \\
140-660\end{array}$ & $\begin{array}{l}24 \\
-\end{array}$ \\
\hline Pitka Creek (PI) & $\begin{array}{l}12.8 \pm 4.5 \\
2.8-19.1\end{array}$ & $\begin{array}{l}11.42 \pm 2.91 \\
3.10-14.80\end{array}$ & $\begin{array}{c}94.5 \pm 18.8 \\
68.1-140.5\end{array}$ & $\begin{array}{l}137.1 \pm 45.7 \\
48.3-246.3\end{array}$ & $\begin{array}{c}405.6 \pm 170 \\
30-740\end{array}$ & $\begin{array}{l}27 \\
-\end{array}$ \\
\hline Tako Creek (TC) & $\begin{array}{c}13.3 \pm 3.6 \\
5.5-19\end{array}$ & $\begin{array}{l}11.79 \pm 2.25 \\
6.74-15.63\end{array}$ & $\begin{array}{r}93.3 \pm 23.5 \\
63.6-150.7\end{array}$ & $\begin{array}{c}157 \pm 38.6 \\
63.5-224.8\end{array}$ & $\begin{array}{c}503.2 \pm 120.4 \\
274-734\end{array}$ & $\begin{array}{l}24 \\
-\end{array}$ \\
\hline Chehishic Creek (CC) & $\begin{array}{l}12.4 \pm 3.5 \\
3.9-18.6\end{array}$ & $\begin{array}{l}10.80 \pm 2.26 \\
5.43-14.50\end{array}$ & $\begin{array}{c}91.1 \pm 19.0 \\
56.8-142.1\end{array}$ & $\begin{array}{c}150 \pm 42.7 \\
78.5-244.3\end{array}$ & $\begin{array}{c}456.9 \pm 114.2 \\
190-644\end{array}$ & $\begin{array}{l}22 \\
-\end{array}$ \\
\hline
\end{tabular}

aField measured

${ }^{\mathrm{b}}$ Tree level Height / DBH ratio $(\mathrm{cm} / \mathrm{cm})$

${ }^{\mathrm{c}}$ At plot establishment

${ }^{\mathrm{d}}$ Mean and standard deviation

eRange

wood (Populus balsamifera ssp. trichocarpa [T. \& G.] Brayshaw). Crown closure was evident within all the plots at all the sites as suggested by the stand level densities (aspen, pine and total), and the CP height and height to the base of the live crown statistics (Table 4) as well as the age of the stands (22 to 39 years since planting). Closed canopy conditions were such that the CP crown recession (height to base of the live crown) was between $3.8 \mathrm{~m}$ and $8.0 \mathrm{~m}$ on average. The canopy was dominated by pine, aspen or a mix of the two species with a total density range from 1350 tph to 18100 tph.
In order to better describe relative stand composition and to facilitate across site comparisons, percent pine composition was calculated using density (total = aspen + pine) for each of the 30 plots at each of the six sites (Fig. 2a, 2b, 2c). The minimum percent pine composition varied by site with the lowest between $1.4 \%$ and $10 \%$ at BE, DG, PI and LL sites; however the minimum at TC and CC was much higher at $21.3 \%$ and $21.6 \%$ respectively. Linear and non-linear models were assessed for fit using total density, aspen and pine density as the dependent variables regressed over percent pine compo- 

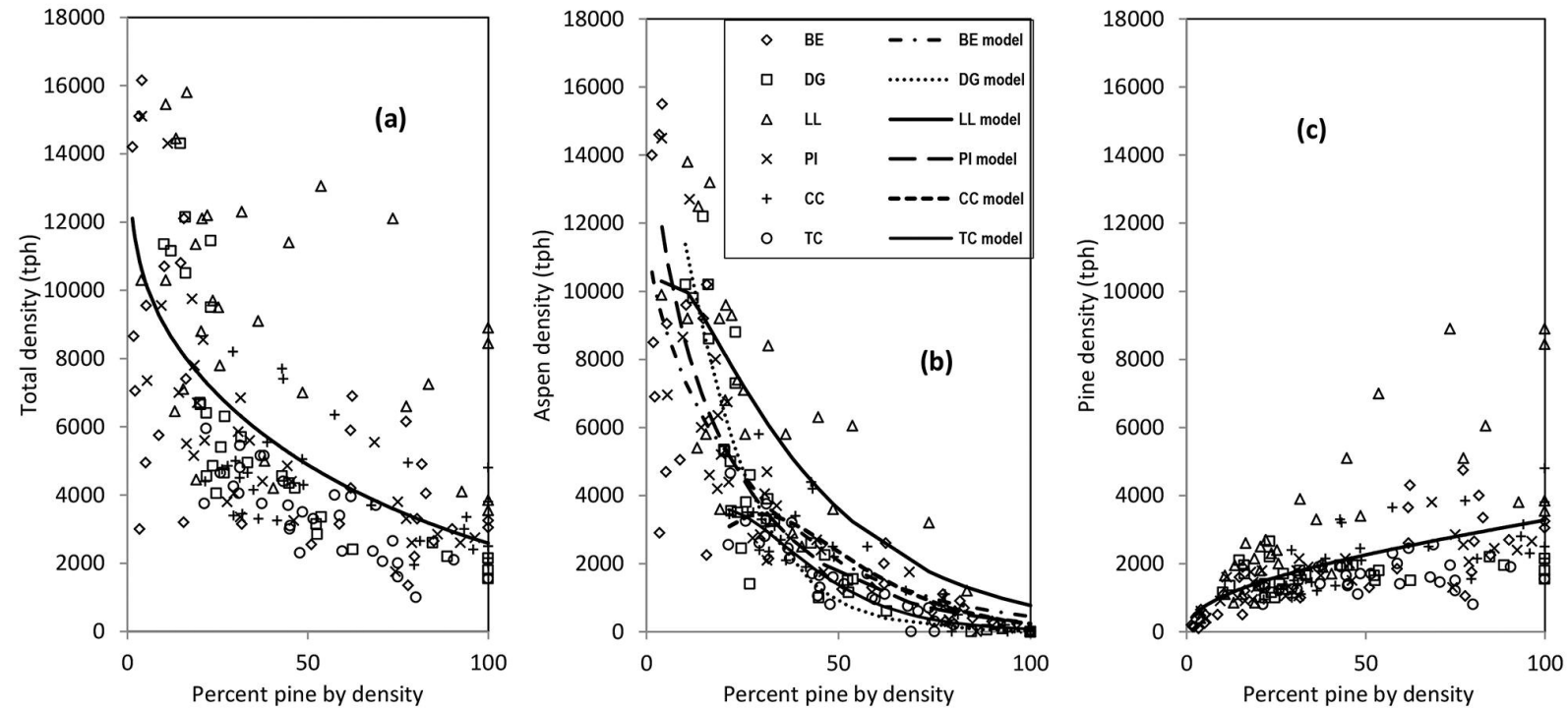

Fig. 2. Site total density without understorey: (a) broken down into the main canopy components aspen; (b) and pine; (c) over percent pine composition (calculated on density basis). Lines illustrate fitted combined exponential - power functions representing the all site model for total density (a) and pine density (c) ( $P<0.0001$ ). Individual site aspen density models are presented in (b). (see Table 5 for model coefficients).

Table 5. Equation coefficients for the fitted type II combined exponential power function model describing total density, aspen or pine density over percent pine composition (by density (PC)) where the dependent variable density (tph for total, aspen or pine) = $\mathrm{aPC}^{\mathrm{b}} e^{\mathrm{cPC}}$ (Main model P-values $<0.0001$ )

\begin{tabular}{|c|c|c|c|c|c|c|c|c|c|}
\hline \multirow[b]{2}{*}{ Density } & \multicolumn{6}{|c|}{ Main model } & \multicolumn{2}{|c|}{ Multiple-site model } & \multirow[b]{2}{*}{$P$ value } \\
\hline & Site $^{\mathbf{a}}$ & a & $\mathbf{b}$ & c & $\mathbf{R}^{2}{ }_{\text {adj }}$ & RMSE $^{\mathrm{b}}$ & variation & $\mathbf{F}$ & \\
\hline \multirow[t]{7}{*}{ Total } & Tamarack Lake (BE) & 11522.2 & -0.115 & -0.0083 & 0.40 & 3126.22 & $\mathrm{PC}$ & 7.34 & 0.0075 \\
\hline & Dog Creek (DG) & 66062.2 & -0.664 & -0.00646 & 0.74 & 1773.985 & $\log (\mathrm{PC})$ & 0.02 & 0.8798 \\
\hline & Loon Lake (LL) & 11830.4 & -0.012 & -0.0056 & 0.12 & 3216.042 & Site & 2.18 & 0.059 \\
\hline & Pitka Creek (PI) & 21059.8 & -0.338 & -0.00614 & 0.63 & 1916.501 & $\log (P C) \times$ Site & 1.72 & 0.1326 \\
\hline & Tako Creek (TC) & 1868.3 & 0.497 & -0.0262 & 0.64 & 742.921 & PC x Site & 0.77 & 0.5741 \\
\hline & Chehishic Creek (CC) & 208.2 & 1.178 & -0.0284 & 0.25 & 1377.397 & - & - & - \\
\hline & All sites & 12727.9 & -0.1003 & -0.0113 & 0.40 & 2695.687 & - & - & - \\
\hline \multirow[t]{6}{*}{ Aspen } & Tamarack Lake & 11215.5 & -0.0525 & -0.0298 & 0.65 & 2775.724 & $\mathrm{PC}$ & 99.87 & $<0.0001$ \\
\hline & Dog Creek & 13402.6 & 0.251 & -0.0736 & 0.82 & 1516.869 & $\log (\mathrm{PC})$ & 12.72 & 0.0005 \\
\hline & Loon Lake & 9039.9 & 0.192 & -0.0334 & 0.69 & 2256.896 & Site & 2.40 & 0.0404 \\
\hline & Pitka Creek & 16363.7 & -0.13 & -0.035 & 0.79 & 1596.861 & $\log (P C) \times$ Site & 2.71 & 0.0226 \\
\hline & Tako Creek & 153.6 & 1.594 & -0.0809 & 0.83 & 498.001 & PC x Site & 2.91 & 0.0158 \\
\hline & Chehishic Creek & 12.609 & 2.348 & -0.0792 & 0.76 & 789.755 & - & - & - \\
\hline \multirow[t]{7}{*}{ Pine } & Tamarack Lake & 137.9 & 0.795 & -0.0055 & 0.64 & 818.486 & $\mathrm{PC}$ & 6.75 & 0.0102 \\
\hline & Dog Creek & 1128.9 & 0.109 & 0.00021 & 0.01 & 386.488 & $\log (\mathrm{PC})$ & 24.82 & $<0.0001$ \\
\hline & Loon Lake & 35.518 & 1.43 & -0.0145 & 0.60 & 1494.177 & Site & 2.08 & 0.0704 \\
\hline & Pitka Creek & 275.8 & 0.543 & -0.00245 & 0.56 & 484.186 & $\log (P C) \times$ Site & 1.73 & 0.1306 \\
\hline & Tako Creek & 29.074 & 1.338 & -0.023 & 0.13 & 388.994 & PC x Site & 0.80 & 0.5487 \\
\hline & Chehishic Creek & 5.01 & 1.882 & -0.023 & 0.37 & 768.867 & - & - & - \\
\hline & All sites & 356.3 & 0.4576 & 0.00111 & 0.29 & 1165.884 & - & - & - \\
\hline
\end{tabular}

aAt site level $n=30$, all sites combined $n=180$

${ }^{b}$ Root mean squared error 
sition. A type II combined exponential power function (Sit and Poulin-Costello 1994) was chosen as a common model to best describe the various density changes with composition (Table 5). Combining all six sites into one model was supported by the multiple-site model results for total and pine density, but not for aspen density. In general, lower percent pine composition was a result of increases in aspen density (and composition) in concert with a decline in pine density.
Stand level volume prediction was explored using linear and non-linear functions relative to a measure of percent stand composition based on pine basal area, pine density (as per Fig. 2) or pine volume with all three providing similar results (data not shown; total $=$ aspen + pine $)$. Fig. 3 presents the pine and aspen stand components for total stand volume over percent pine composition by volume for each site. Linear models were used since no improvement was found using
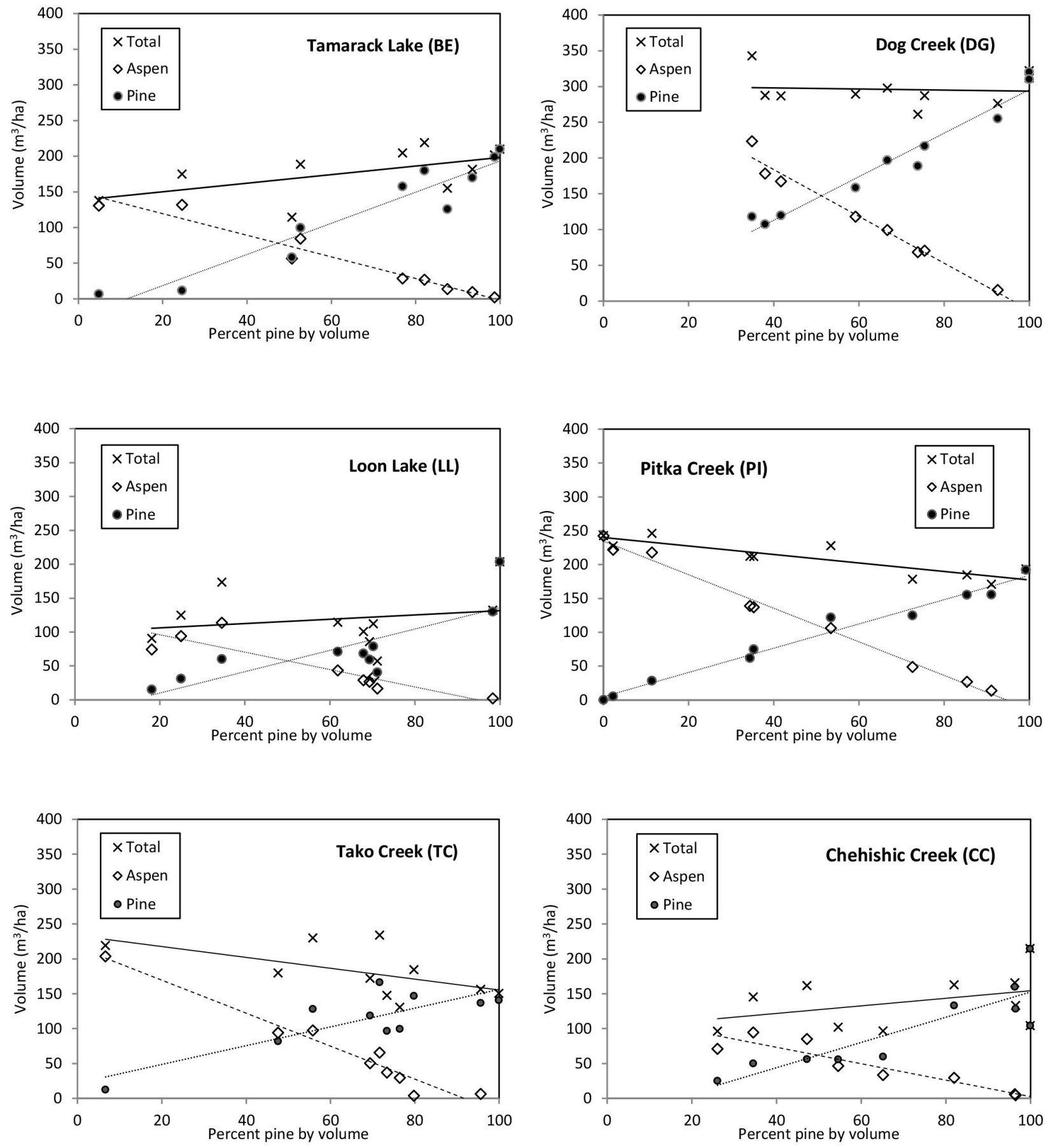

Fig. 3. Total, aspen and pine volumes over percent pine composition by volume for each site (10 plots per site). Lines represent fitted linear equations (Table 6). 
Table 6. Equation coefficients for the linear model describing each site stand volume relationship over percent pine composition by volume (VPc) where volume $\left(\mathrm{m}^{3} / \mathrm{ha}\right.$ for total, aspen or pine) $=\mathrm{a}+\mathrm{b}$ VPc.

\begin{tabular}{|c|c|c|c|c|c|c|c|c|c|}
\hline \multirow[b]{2}{*}{ Volume } & \multicolumn{6}{|c|}{ Main model } & \multicolumn{2}{|c|}{ Multiple-site model } & \multirow[b]{2}{*}{$P$ value } \\
\hline & Site $^{\mathbf{a}}$ & a & b & $\mathbf{R}_{\text {adj }}^{2}$ & RMSE $^{\mathbf{b}}$ & $P$ value & $\begin{array}{l}\text { Source of } \\
\text { variation }\end{array}$ & $\mathbf{F}$ & \\
\hline \multirow[t]{6}{*}{ Total } & Tamarack Lake (BE) & 138.211 & 0.602 & 0.26 & 29.02 & 0.0758 & VPc & 0.00 & 0.9811 \\
\hline & Dog Creek (DG) & 301.251 & -0.077 & -0.12 & 24.99 & 0.8257 & Site & 10.24 & $<0.0001$ \\
\hline & Loon Lake (LL) & 99.796 & 0.3175 & -0.08 & 44.387 & 0.5647 & VPc $x$ Site & 2.99 & 0.0197 \\
\hline & Pitka Creek (PI) & 239.99 & -0.627 & 0.74 & 13.677 & 0.0009 & - & - & - \\
\hline & Tako Creek (TC) & 233.193 & -0.779 & 0.24 & 31.789 & 0.0862 & - & - & - \\
\hline & Chehishic Creek (CC) & 100.192 & 0.543 & 0.05 & 38.07 & 0.2582 & - & - & - \\
\hline \multirow[t]{6}{*}{ Aspen } & Tamarack Lake & 149.734 & -1.51 & 0.95 & 11.287 & $<0.0001$ & VPc & 1051.07 & $<0.0001$ \\
\hline & Dog Creek & 307.187 & -3.125 & 0.98 & 11.0727 & $<0.0001$ & Site & 46.18 & $<0.0001$ \\
\hline & Loon Lake & 120.340 & -1.251 & 0.81 & - & 0.0002 & VPc $x$ Site & 24.95 & $<0.0001$ \\
\hline & Pitka Creek & 233.432 & -2.432 & 0.99 & 8.921 & $<0.0001$ & - & - & - \\
\hline & Tako Creek & 211.817 & -2.262 & 0.94 & 14.988 & $<0.0001$ & - & - & - \\
\hline & Chehishic Creek & 121.357 & -1.199 & 0.88 & 12.338 & $<0.0001$ & - & - & - \\
\hline \multirow[t]{6}{*}{ Pine } & Tamarack Lake & -25.013 & 2.183 & 0.90 & 23.791 & $<0.0001$ & VPc & 266.04 & $<0.0001$ \\
\hline & Dog Creek & -8.874 & 3.044 & 0.95 & 17.728 & $<0.0001$ & Site & 0.93 & 0.4697 \\
\hline & Loon Lake & -21.25 & 1.573 & 0.61 & 34.047 & 0.0047 & VPc x Site & 3.36 & 0.0110 \\
\hline & Pitka Creek & 5.011 & 1.791 & 0.98 & 10.65 & $<0.0001$ & - & - & - \\
\hline & Tako Creek & 22.029 & 1.343 & 0.63 & 26.413 & 0.0037 & - & - & - \\
\hline & Chehishic Creek & -28.438 & 1.811 & 0.71 & 32.169 & 0.0013 & - & - & - \\
\hline
\end{tabular}

${ }^{a}$ At site level $\mathrm{n}=10$, all sites combined $\mathrm{n}=60$

${ }^{b}$ Root mean squared error

non-linear functions. Table 6 presents the linear model statistics at all sites, with the aspen and pine volume results indicating a significant decrease in aspen volume with increasing pine composition. Total stand volume did not significantly change with pine composition on five of the six sites (PI site; $\mathrm{P}=0.0009)$. Multiple-site model results suggested common all sites models could not be used to describe total, pine or aspen volume.

Linear models were used to fit pine merchantable volume (square root transformation was required) to percent pine composition (on a volume basis) for each of the sites (Fig. 4a), describing the significant increase in merchantable pine volume with increasing percent pine composition (Table 7). Pine merchantable volume was negatively correlated with increasing aspen composition. The site-dependent slope of the pine merchantable volume linear models indicated a greater sensitivity to percent pine composition at the DG and PI sites with smaller sensitivity noted at the LL and CC sites. Linear models were also used to describe the pine basal area to aspen basal area site composition relationships (Fig. 4b and Table 7). The negative correlations (slope (b) parameters) between pine and aspen basal area at each site indicated the relationship to be between 0.61 to 0.87 for DG, LL, PI and TC sites with $\mathrm{BE}$ and $\mathrm{CC}$ sites steeper than a 1:1 ratio at 1.15 and 1.11 respectively.

Merchantable volumes by DBH class for select plots by site are presented in Fig. 5a and Fig. 5b. No statistical analysis was attempted. The DBH class distribution of merchantable volume for the $100 \%$ pine plots are shown for each site as well as a select series of plots with increased percent composition of aspen (declining pine composition). This plot progression of increase in aspen composition indicates where the decline in pine merchantable volume occurs across the DBH classes. At all six sites, the largest pine merchantable volumes were found either in the $12.5 \mathrm{~cm}$ or $17.5 \mathrm{~cm} \mathrm{DBH}$ classes. Maximum aspen merchantable volume by DBH class was, in general, much smaller than pine for each site, except for plots $>85 \%$ aspen composition at sites PI and TC. At each site, comparing plots that increased in aspen composition showed a concomitant decline in pine merchantable volume across the $12.5 \mathrm{~cm}$ DBH class for all sites except site PI. The $17.5 \mathrm{~cm}$ DBH class showed a similar pine volume decline between plots with increasing aspen composition on all sites except CC and TC.

\section{Discussion}

Regression sampling of six independent post-FG pine plantations allowed a retrospective assessment of the impact of varying levels of aspen competition. The silviculture history of these six sites indicated aspen control treatments were used on four of the plantations. Vegetation management practises in $\mathrm{BC}$ have historically used a variety of brushing treatments such as manual cutting and herbicide application to ensure the survival and growth of planted conifers (Comeau et al. 1999). At a minimum of 18 years after brushing disturbance (a minimum of 27 years after disturbance for the two nonbrushed sites), the regression sampling indicated aspen had an average dominant (top) height similar to, if not taller than, the average pine dominant height (Table 3 ). The only site where aspen top height was found to be less than the pine top height occurred at $\mathrm{BE}$ where two operational aspen control treatments had occurred (herbicide and a manual brushing). Centre pine (CP) DBH and height, at four of the six sites 

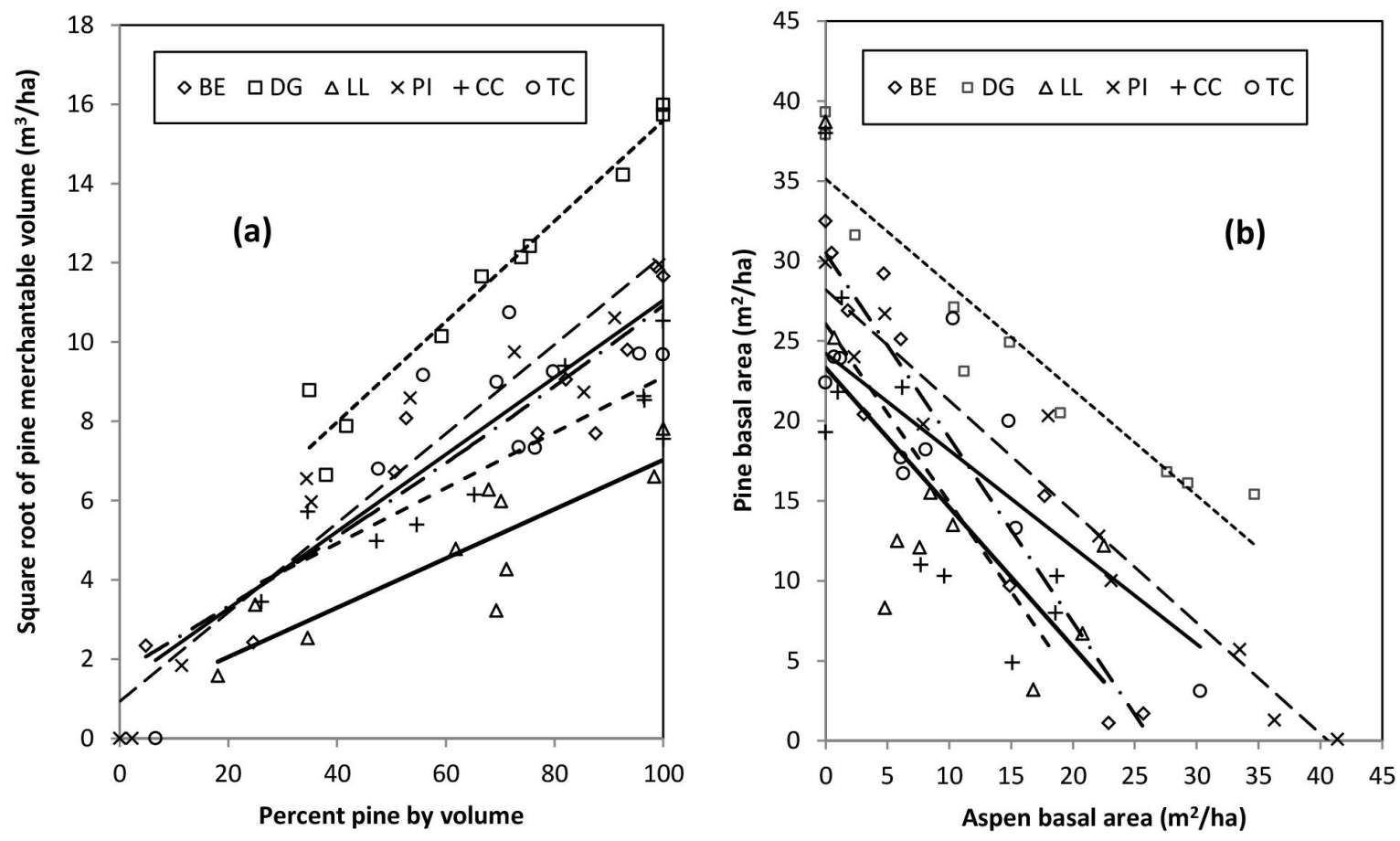

Fig. 4. Square root of pine merchantable volume by percent pine composition for each site (a). Pine basal area over aspen basal area (b). Formatted lines illustrate linear equations found in Table 7 by site.

Table 7. Regression parameters for the two linear models $Y=a+b X$ by site. See Figure 4 , $a \& b$, which graphically presents the data and accompanying models.

\begin{tabular}{|c|c|c|c|c|c|c|c|c|c|c|}
\hline \multicolumn{8}{|c|}{ Main model } & \multicolumn{3}{|c|}{ Multiple-site model } \\
\hline $\mathbf{Y}$ & $\mathbf{X}$ & Site $^{\mathrm{a}}$ & a & $\mathbf{b}$ & $\mathbf{R}_{\text {adj }}^{2}$ & RMSE $^{\mathrm{d}}$ & $P$ value & $\begin{array}{l}\text { Source of } \\
\text { variation }\end{array}$ & $\mathbf{F}$ & $P$ value \\
\hline \multirow{6}{*}{$\begin{array}{l}\text { Square root of Pine } \\
\text { merchantable } \\
\text { volume }^{\mathrm{ab}}\end{array}$} & he $\%$ Pine & Tamarack Lake (BE) & 1.976 & 0.089 & 0.91 & 0.983 & $<0.0001$ & $\mathrm{X}$ & 298.7 & $<0.0001$ \\
\hline & & Dog Creek (DG) & 3.081 & 0.126 & 0.95 & 0.699 & $<0.0001$ & Site & 0.90 & 0.4892 \\
\hline & & Loon Lake (LL) & 0.850 & 0.062 & 0.73 & 1.046 & 0.0011 & $\mathrm{X} \times$ Site & 3.60 & 0.0076 \\
\hline & & Pitka Creek (PI) & 1.069 & 0.112 & 0.90 & 1.403 & $<0.0001$ & - & - & - \\
\hline & & Tako Creek (TC) & 0.998 & 0.106 & 0.74 & 1.553 & 0.0009 & - & - & - \\
\hline & & Chehishic Creek (CC) & 2.432 & 0.067 & 0.78 & 1.065 & 0.0005 & - & - & - \\
\hline \multirow[t]{6}{*}{ Pine basal area } & Aspen basal area & Tamarack Lake & 30.464 & -1.152 & 0.89 & 3.853 & $<0.0001$ & $\mathrm{X}$ & 136.3 & $<0.0001$ \\
\hline & & Dog Creek & 35.131 & -0.66 & 0.89 & 2.881 & $<0.0001$ & Site & 3.06 & 0.0177 \\
\hline & & Loon Lake & 23.311 & -0.871 & 0.38 & 8.061 & 0.0340 & $\mathrm{X} x$ Site & 1.85 & 0.1209 \\
\hline & & Pitka Creek & 28.211 & -0.694 & 0.94 & 2.530 & $<0.0001$ & - & - & - \\
\hline & & Tako Creek & 24.215 & -0.606 & 0.64 & 4.032 & 0.0033 & - & - & - \\
\hline & & Chehishic Creek & 26.050 & -1.114 & 0.61 & 6.478 & 0.0048 & - & - & - \\
\hline
\end{tabular}

aAt site level $\mathrm{n}=10$, all sites combined $\mathrm{n}=60$

${ }^{b}$ Merchantable volume for pine component $(30 \mathrm{~cm}$ stump and $\mathrm{DBH}>5 \mathrm{~cm}$ )

'Pine composition by volume

${ }^{\mathrm{d}}$ Root mean squared error 

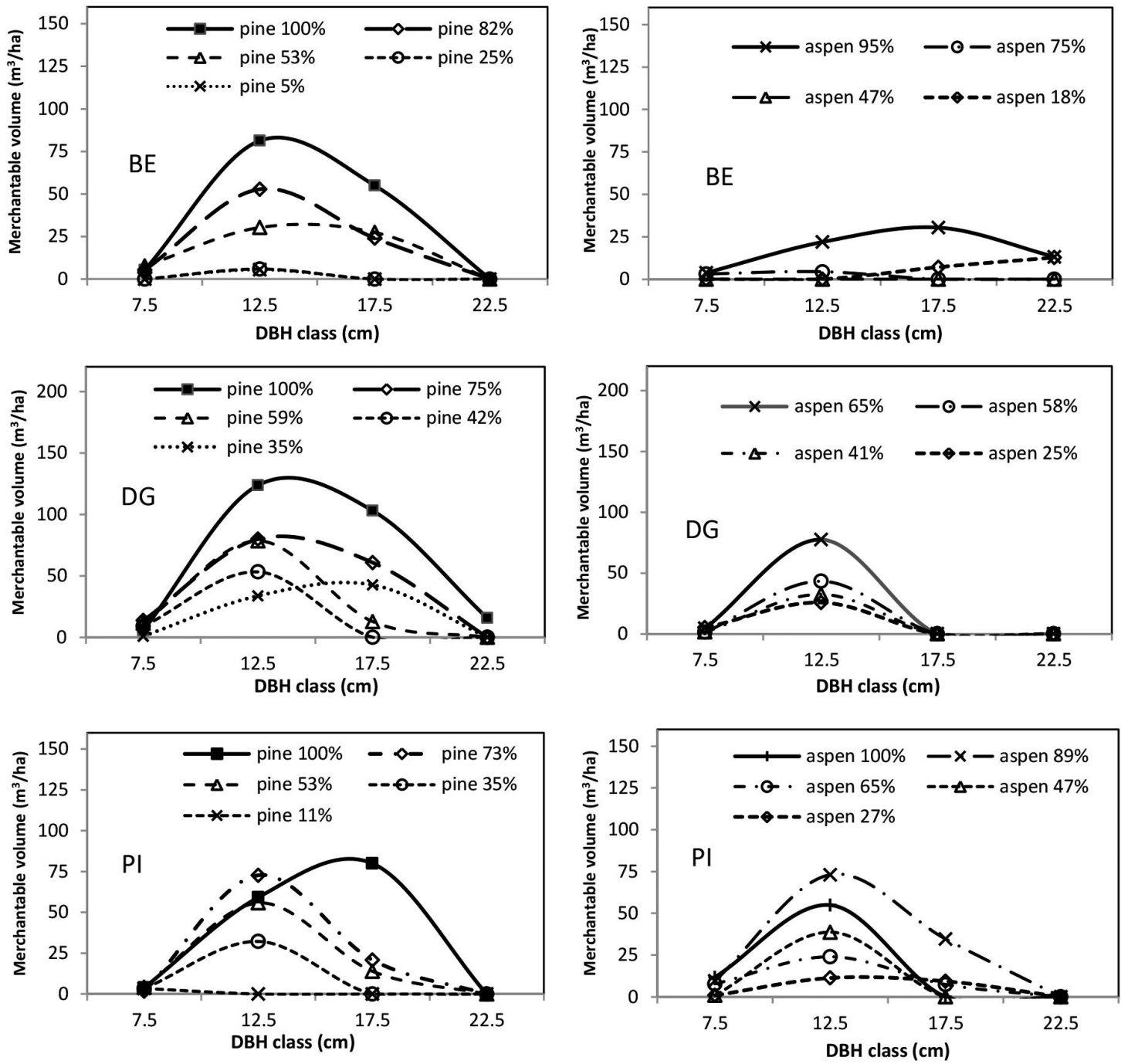

Fig. 5a. Select merchantable volume DBH classes presented for pine (left) and aspen (right) components for three of the six sites. Only site BE received a brushing treatment (hack-n-squirt with glyphosate and manual cutting). Both DG and PL sites received no brush removal treatments. Symbols represent pine and aspen components of the same plot whose total merchantable volume by site and plot is $100 \%$.

(BE and CC were the exceptions), were found to significantly decline with increasing aspen density and total stand density (data not shown; $\mathrm{P}<0.05$ ). This was expected since plots were chosen across a range of increasing levels of aspen competition and strong negative associations between the two species have been reported previously (Newsome et al. 2008, Harper et al. 2009). A similar negative growth association has been shown between jack pine (Pinus banksiana) and aspen (Kenkel 1994). The noted CP size decline with increasing total density was due to the site specific, exponential increases in aspen densities (Fig. 2, Table 5). Even though two of the sites (BE and LL) received manual aspen cutting (old stumps were observed confirming treatment) and two had received aerial herbicide application (TC and $\mathrm{CC}$ ), the aspen was found to have recovered in many of the treated areas. This is not unreasonable since manual cutting treatments have been shown to result in rapid re-sprouting with reports of 1.5 to 3.0 $\mathrm{m}$ annual height growth (Peterson and Peterson 1995). Cut stump application of glyphosate can also have limited success when poor herbicide translocation fails to provide complete control (McCulloch and Kabzems 2009). This is a possible scenario for the BE site where the aspen recovered in many cases into dominant and co-dominant canopy positions after a pre-plant cut stump glyphosate treatment and a subsequent manual brushing that occurred seven years after planting (Table 1). Seven years is a long period that undoubtedly acerbated the impacts of vigorous aspen regrowth on planted pine growth and survival. Aerial glyphosate application was chosen to control aspen at TC and CC sites seven years and four years respectively, after site preparation. Glyphosate aerial 

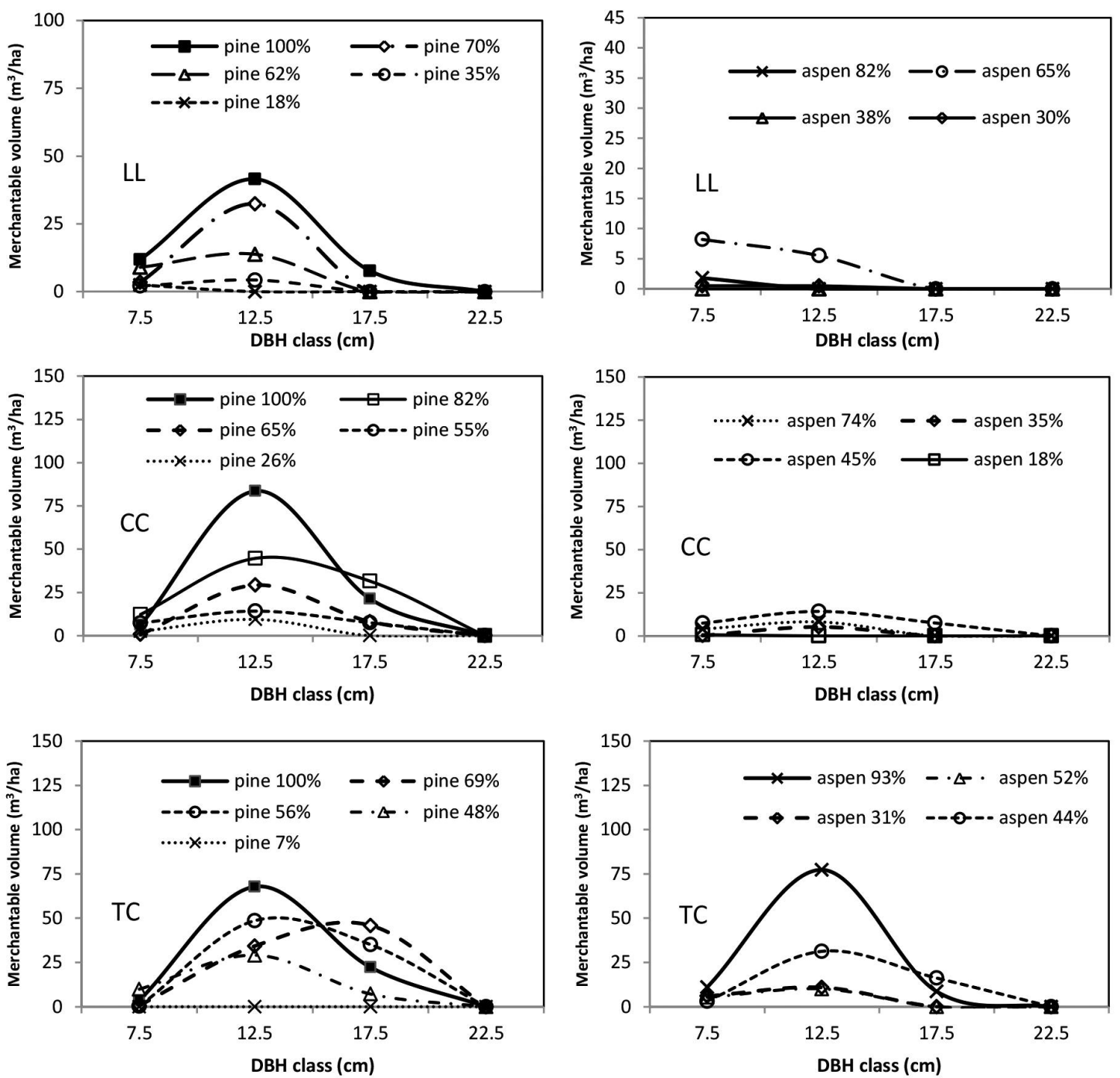

Fig. 5h. Select merchantable volume DBH classes presented for pine (left) and aspen (right) components for three of the six sites. All three received either manual (LL) or aerial herbicide treatment (CC and TC) to control broadleaf competition. Symbols represent pine and aspen components of the same plot whose total merchantable volume by site and plot is $100 \%$.

application is considered highly cost effective in controlling aspen (Dampier et al. 2006). However, aerial application efficacy can be reduced for a number of reasons; in particular, areas with vigorous aspen may result in inconsistent control if tall, dense aspen foliage restricts herbicide coverage. Aspen variability between and within sites can be high, reflecting the combination of clonal differences in aspen root sucker density and vigour, the distribution of pre-harvest aspen tree basal area and logging history (Frey et al. 2003).

At all six sites, aspen was observed in a variety of proximity and relative size arrangements with pine, where canopy stratification apparently had been restricted by the shade intolerance and the height growth patterns of both species (Larson 1992). In general, CP plot neighbourhoods can be crudely categorized as either intimate pine-aspen mixed- woods of similar height and canopy class (Ix), suppressed or intermediate pine composition within dominant aspen clumps or canopies $(A p)$ or, pure pine neighbourhoods with minor aspen (suppressed to co-dominant) composition $(\mathrm{Pa})$. These generalized categories of interspecific relationship can be helpful in simplifying this complexity; however, such simplification fails to capture the spatial and temporal dynamics at play.

The presence of abundant aspen did not always show a significant decline in $\mathrm{CP}$ growth with changes in species composition. At the BE and CC sites, $\mathrm{CP}$ DBH and height were not correlated with increasing aspen density which suggested the brushing treatments at these two sites were effective in increasing the surviving pine size. At all sites, many of the select CP from moderate aspen competition neighbourhoods 
were found in dominant or codominant canopy positions ( $I x$ positions) as opposed to Ap positions which was a more common occurrence in many of the high to extreme aspen competition environments. At $\mathrm{BE}$ and $\mathrm{CC}$ sites, $\mathrm{CP}$ from high to extreme aspen competition plots were more likely to have their canopy positions as intermediate to dominant as opposed to suppressed. This suggests brushing had benefitted the surviving CP pine size through more favourable canopy position but, as will be further discussed, this benefit did not prevent a pine density decline.

It can also be inferred from the significant presence of aspen at all the sites that pine density and concurrent pine canopy development was insufficient in many areas to suppress aspen development or recovery. Persistent canopy openings or gaps will allow recovering aspen to occupy canopy space. Higher planting densities, vigorous stock and strategic brushing treatments may be needed to maintain pine survival and growth, and to ensure pine canopy dominance. Early pine crown closure and canopy dominance objectives need to consider years to canopy closure. The ability of aspen to sucker post-disturbance is well-known and resulting high densities will reduce light availability to neighbouring conifers (Lieffers et al. 1999, Comeau et al. 2006). If aspen is allowed to "catch-up" after brushing, the inevitable competition impacts to planted pine growth and survival will return. Knowledge of how aspen responds to various brushing treatments can be used to help set acceptable thresholds of aspen size and frequency within mixedwood prescriptions (Comeau 2014).

\section{Density}

The non-linear exponential-power equations adequately describe the site level increase in total density or aspen density with declining percent pine composition (Fig. 2; Table 5), as well as the decline in pine density. Multiple-site model results indicated a single model combining data from all six sites could be used to predict total density and pine density over percent composition. However, the exponential increase in aspen density with declining pine composition was sitedependent. It is logical to expect differences in site history, including site preparation and brushing treatments, would have influenced aspen density but not necessarily total or pine densities. The breakdown of total density into pine and aspen components highlights the contribution of each species at the stand level, in particular the influence of aspen on pine densities. Increasing densities of pine due to natural ingress were observed where aspen densities (composition) were low (Fig. 2c). Similarly plots with high aspen densities were observed to have little if any natural pine ingress. The negative correlation of declining pine density (both lack of ingress and planted pine mortality) with increasing aspen composition can be related to the increased pine suppression associated with aspen dominance (Kobe and Coates 1997, Coates and Burton 1999) and reduced understorey light levels (Comeau et al. 2006). Similar correlations have been noted in mixedwood forests in Alberta (Yao et al. 2001). Pine density declined to < 1000 tph in plots where aspen composition was greater than approximately $88 \%$ ( $<12 \%$ pine by density). In general, high aspen composition plots can be classified as Ap or aspendominated canopies where suppression has resulted in high mortality of planted pine. Surviving suppressed and interme- diate pine had height to diameter ratios > 100 and were stunted with poor crown, diameter and height growth. However, in the case of site BE and less so CC, brushing appears to have favoured a few surviving CPs that had maintained dominant and co-dominant canopy positions within the mainly aspen canopy. These were pine of similar height and canopy class as the dominant aspen or in a $I x$ mixedwood position.

\section{Total Volume}

At each site, stand level volume summarization (Fig. 3; Table 6) explored the productivity of aspen and pine mixtures by comparing the total and component yield patterns using simple linear equations. Volume was chosen to describe productivity due to its ease of comparison to growth and yield model estimates (Mitchell et al. 2004, Bokala et al. 2013) and timber supply metrics. However, Pretzch (2009) has indicated biomass may be a more accurate measure of species performance and productivity. It is to be noted that stand volume, density or basal area may provide different mixture proportions to those based on biomass. Cross-species diagrams of stand and species level volume were used to explore species mixture productivity. Experiments involving species mixtures and productivity have preferred the use of replacement series and additive designs to control density and proportion (Radosevich and Osteryoung 1987, Kelty 1992). The six operational situations described here are much more complex with the additive influences of increasing aspen density and distribution on the spatially uniform planted pine confounded by pine ingress and mortality interactions at the site level. The retrospective sampling on these operational cutblocks precluded any assumptions of experimental control designed to simplify the inherent complexity of species interactions. Expected site differences in linear equation parameters for volume were confirmed by testing the multiple-site models. As a result, the statistical evidence did not support an all-sites equation for total volume and aspen and pine volume components.

For five of the six sites there was no significant change in total volume with percent pine composition (Table 6; $\mathrm{P} \geq$ 0.0758). This indicated mixed aspen and pine plots were not any more productive than plots containing dominant canopies or monocultures of either aspen or pine on the same site. The one exception, the PI site, did find total volume significantly increased as aspen composition increased $(\mathrm{P}=0.0009)$. The PI site had received no brushing treatment which allowed the aspen to surpass the productivity of the pine. Top height of aspen on this site was $4.1 \mathrm{~m}$ taller than that of the pine at year 27. Logically, sites where aspen brushing had occurred (BE, LL, TC and CC) would have had lower total yields as aspen composition increased. Regression evidence from the four brushed sites did not prove this to be the case. As well, the DG site, which had no history of brushing, saw no change in stand productivity with composition. There are several possibilities that could lead to this result: 1 ) aspen recovered quickly post-brushing at rates of growth superior to that of the neighbouring pine; and, 2) aspen operational brushing can be inconsistent and the results variable, leading to gaps or areas with poor treatment efficacy or no treatment at all.

The lack of evidence supporting a productivity change (total yield) across the aspen-pine mixtures is consistent with 
recent discussions on mixed-species interactions where species niche separation has been related to shade-tolerance (Pretzsch 2009). In the meta-analysis by Zhang et al. (2012) of 54 studies worldwide, the productivity of mixed species forests was found to be on average higher than monocultures. Mason and Connolly (2014) provided an example of positive over yielding in mixed stands of Norway spruce (Picea abies (L.) Karst.) and Scots pine (Pinus sylvestris L.) as a result of facilitative effects. Exceptions, however, have been reported with mixtures of shade-tolerant white spruce (Picea glauca (Moench) Voss) with shade-intolerant aspen that did not show improved productivity (Groot et al. 2014). Combinations of shade-intolerant species such as lodgepole pine with larch (Larix occidentalis Nutt.) (Chen et al. 2003) or jack pine with aspen (Cavard et al. 2011) have not shown productivity improvements when found in mixtures. The lack of clear niche segregation within mixtures of shade-intolerant species such as aspen and pine may result in more intense aboveground competition with productivity determined more by density than complementary effects (Forrester 2014). Cavard et al. (2011) suggested that there is no benefit to mixing two shade-intolerant species such as aspen and pine. St. Clair et al. (2013) described the influence of aspen in mixed species forests as a balance between facilitation and competition which changes depending upon conifer species, forest type and stage of stand development. The complexity of understanding mixed species resource requirements, spatial and temporal growth dynamics (Kelty 1992) in concert with confounding factors such as density, stand age and stand structure (Forrester 2014) makes understanding mixed species management a significant challenge.

Aspen and pine volume equations (Table 6) provided sitedependent, linear model slope coefficients $(b)$ which suggested a competitive reduction relationship between aspen and pine. At all six sites, a significant decline in pine component volume occurred with concurrent increases in aspen volume. Even though similar trends appeared across all sites, the linear equations for each were statistically unique. The fit statistics $\left(\mathrm{R}^{2}{ }_{\text {adj }}\right)$ were very good for the aspen volume equations $\left(\mathrm{R}^{2}{ }_{\text {adj }}=0.81-0.99\right)$ but less so for pine $\left(\mathrm{R}^{2}{ }_{\text {adj }}=0.61-\right.$ $0.98)$; however, the total volume fits were poor. Interestingly, the crossover of the linear models describing aspen and pine volumes occurred generally in the same region of $45 \%-55 \%$ pine composition at each site, supporting the conclusion that the impact of aspen on pine volume at these sites is linear, consistent and competitive in nature. A comparison of the various site model parameters suggested site differences exist in species response sensitivity. The absolute ratio of the model slopes (rates of change) for pine over aspen quantifies the sensitivity of pine volume to changes in composition relative to the concurrent aspen volume sensitivity. This ratio indicated pine volume change relative to aspen varied with site with the highest sensitivity found at sites $\mathrm{BE}$ and $\mathrm{CC}$ with ratios of 1.45 and 1.51 respectively and least responsive at sites PI and TC with ratios of 0.74 and 0.59 respectively. A ratio $>1.0$ can be interpreted as pine volume increasing with composition change at a rate greater than the concurrent rate of aspen volume decline. At ratios $<1.0$ pine volume increased less than the rate of aspen volume decline. It remains to be seen whether this statistic represents a measure of relative competitive reduction between aspen and pine however; the results suggest pine had a more robust or superior growth performance relative to aspen on the BE, LL or CC sites only and that pine growth was inferior to aspen at the PI and TC sites. The DG site ratio suggested no difference in growth performance between aspen and pine.

\section{Merchantable Volume \& Basal Area}

Linear equations were also used to describe pine merchantable volume versus percent pine composition for each site (Fig. 4a, Table 7). Square root transformation was required to adequately fit the pine merchantable volume to percent composition. As a result, the exponential (squared) decline in absolute pine merchantable volume suggested pine was highly sensitive to increases in aspen composition at pine composition levels $>75 \%$, more so than changes at low pine compositions $<50 \%$. At every site except TC, the maximum pine merchantable volume was found in plots $\geq 97 \%$ pine composition (TC maximum was at $72 \%$ ). The maximum pine merchantable volume was observed at the DG site with approximately $250 \mathrm{~m}^{3} /$ ha at age 39 . The site with the lowest pine merchantable volume was LL with approximately 60 $\mathrm{m}^{3} /$ ha at age 24 .

Basal area equations (Fig. 4b, Table 7) described the same site-specific, negative pine to aspen growth relationships noted with volume, providing evidence of a linear diameter growth reduction between the two species. At the site level, pine basal area was highly sensitive to even small increases in neighbourhood aspen basal area. The slopes of the sitedependent basal area response equations did not appear to be related to aspen brushing treatments nor any obvious site level variables. In general, as the proportion of aspen increased, a decline in pine basal area and merchantable volume occurred. Similar basal area observations have been documented with loblolly pine (Pinus taeda L.) in response to hardwood competition (Walstad and Kuch 1987, Miller et al. 2003). As already discussed, many factors could potentially influence the relative competitiveness of the two species. The shade-intolerant pine and aspen observed on these SBS sites are directly competing for crown space occupancy when found intimately mixed (Ix). The relative size of the available canopy growing space will influence individual tree crown expansion and lift. Clumped spatial arrangements (such as commonly found with aspen) will likely minimize interspecific crown interactions as opposed to intimate mixedwood arrangements (Kenkel 1994). However, at these sites the planting arrangement imposed a regular placement of pine that was additive to the regenerating aspen spatial coverage and thereby imposed a range of competitive neighbourhoods. The presence of vigorous aspen clumps would have the greatest potential impact on pine survival and growth, and without intervention the result would be aspen canopy dominance within the clump. Brushing treatments may allow more pine to capture a place in the canopy depending upon the size, vigour and species of neighbours and the density of the developing pine stand. Temporal changes to spatial crown growth interactions between shade-intolerant tree species can be further defined at the tree level through analysis of species crown efficiency and productivity (Pretzsch 2009). Inherent differences in species productivity interact with silvicultural treatments that influence stand density and mortality such as site preparation, brushing and planting, thereby contributing to 
variation in competitive or facilitative effects between mixed species (Forrester 2014).

The pine merchantable volume decline with an increase in aspen composition occurred primarily in the larger tree size classes (12.5 cm and $17.5 \mathrm{~cm}$; Fig. 5a and Fig. 5b). A shift in $\mathrm{DBH}$ distribution to the left with increases in aspen composition was apparent at sites BE, DG and PI. A similar observational shift in loblolly pine $\mathrm{DBH}$ distribution as a result of increases in hardwood composition has been documented (Walstad and Kuch 1987).

Aspen merchantable volume $\mathrm{DBH}$ classes at sites $\mathrm{BE}, \mathrm{LL}$ and CC had less than $50 \%$ of the comparable pine merchantable volumes for a similar percent composition. At these three sites, early stand establishment brushing treatments reduced aspen tree size. However, some aspen were found in the $17.5 \mathrm{~cm}$ or $22.5 \mathrm{~cm} \mathrm{DBH}$ classes which suggested either inconsistent brushing results (BE) and/or superior growth performance from a few individuals. Any aspen missed during a brushing treatment in effect would benefit from an unintended spacing treatment.

\section{Management Implications}

Trembling aspen, a common component of northern BC forests, presents significant challenges to the current system of conifer-centric timber and resource management (Lieffers et al. 2008, Harper and Roach 2014). This paper provides new information on established SBS zone aspen-pine mixedwoods and the potential impacts of aspen on managed pine stand growth and yield. Given the high sensitivity of pine volume and basal area to even small amounts of neighbouring aspen, significant overestimation of pine merchantable volume could result if allowances are not made during timber supply analysis. Observations of significant aspen composition within operational SBS pine plantations reaffirm the potential of vigorous aspen to recover from harvesting and brushing disturbances. Additional surveys or monitoring of aspen-prone areas post-free growing would provide important information on potential aspen recovery concerns. Spatially accurate inventories will be required to document the amount and distribution of aspen and other hardwoods found within post-free growing pine plantations to ensure accurate timber supply projections.

This retrospective study of six post-free growing SBS pine plantations found aspen and pine not in stratified mixtures (Smith 1986) but directly competing for canopy positions where historical dominance patterns were influenced by aspen density and distribution, aspen brushing treatments, shade-intolerance and species growth performance. Discussions on the stand dynamics and structural concepts associated with stratified mixed species stands do not apply to these shade-intolerant aspen-pine mixtures. Mixtures of aspen and pine are not any more productive than pure stands since in general, single-canopied mixtures are dependent on individual species productivity and crown-growing space competition. Local species differences in productivity and density may be important in defining the relative species interactions. As suggested by Forrester (2014), the relative complementary response of mixed species interactions depends upon growing conditions (productivity). In the case of aspen and pine, it is reasonable to suggest lower productivity sites will reduce competitive interactions. A better understanding of the fac- tors affecting aspen development and competition with conifers is needed since others have indicated changes in climatic conditions may directly influence aspen productivity (Brandt et al. 2003, Kljun et al. 2006, Heineman et al. 2010).

Other studies of young pine within mixed aspen and pine stands have been used to suggest threshold aspen densities where tree-level pine growth appears unimpeded (Newsome 1999, Newsome et al. 2008, Dhar et al. 2015). The stand-level results presented here from older stands are not suggestive of an aspen threshold where pine growth is unimpeded. The results suggest a linear relationship between aspen composition and pine volumes and pine and aspen basal area. Publications that have reported aspen thresholds based on pine diameter growth range in density from 500 to 5000 tph for BC SBS locations. However, much of this work does not present treatments where zero or near zero aspen competition exists, but rather relies on small neighbourhood plot assessments of aspen taller than the subject pine to quantify and interpret the impacts of competition. Without a quantitative measure of a near zero aspen competition neighbourhood (pine monoculture), the interspecific competition range is truncated and maximum pine response is undefined (Wagner 2000, Simard et al. 2005). The results presented here represent stand-level assessments that compile competitive impacts across the various $\mathrm{DBH}$ classes that exist, influenced by not only light and canopy space competition but also underground resource competition as part of the stand dynamics of the stem exclusion phase. Future analysis of the various individual CP competition neighbourhoods may help describe tree-level details of interspecific crown interactions including measures of proximity and relative size that may help understand how tree-level competition for aspen and pine mixedwoods can link to stand-level forest productivity.

\section{Acknowledgements}

This project was funded by the British Columbia Ministry of Forests, Lands and Natural Resource Operations. Technical advice and counsel were provided by Phil Comeau, Cosmin Filipescu, Dave Goldie, Jim Goudie, Catherine Bealle Statland and Louise de Montigny. Statistical advice and review were provided by Peter Ott.

\section{References}

B.C. Ministry of Forests, Lands and Natural Resource Operations (BC MFLNRO). 2012. Beyond the beetle: a midterm timber supply action plan. Available from: http://www. for.gov.bc.ca/hfp/mountain_pine_beetle/mid-term-timbersupply-project/MTTS-Action-Plan-201210.pdf

B.C. Ministry of Forests, Lands and Natural Resource Operations (BC MFLNRO). 2013. Silviculture surveys procedures manual. Available from: http://www.for.gov.bc.ca/ $\mathrm{hfp} /$ silviculture/Surveys/SilvicultureSurveyProcedures Manual-April_1_2013.pdf

B.C. Ministry of Forests, Lands and Natural Resource Operations (BC MFLNRO). 2015. Forest and Range Practices Act. Victoria, B.C. Available from: http://www.bclaws.ca/ Recon/document/ID/freeside/00_02069_01

Bokalo, M., K.J. Stadt, P.G. Comeau and S.J. Titus. 2013. The validation of the Mixedwood Growth Model (MGM) for use in forest management decision-making. Forests 4:1-27. 
Brandt, J.P., H.F. Cerezke, K.I. Mallett, W.J.A. Volney and J.D. Weber. 2003. Factors affecting trembling aspen (Populus tremuloides Michx.) health in the boreal forest of Alberta, Saskatchewan, and Manitoba, Canada. For. Ecol. Manage. 178: 287-300.

Cavard, X., Y. Bergeron, H.Y.H. Chen, D. Pare, J. Laganiere and B. Brassard. 2011. Competition and facilitation between tree species change with stand development. Oikos 120: 1683-1695.

Chen H.Y.H., K. Klinka and G.J. Kayahara. 1996. Effects of light on growth, crown architecture, and specific leaf area for naturally established Pinus contorta var. latifolia and Pseudotsuga menziesii var. glauca saplings. Can. J. For. Res. 26: 1149-1157.

Chen, H.Y.H., K. Klinka, A.-H. Mathey, X. Wang, P. Varga and C. Chourmouzis. 2003. Are mixed- species stands more productive than single-species stands: An empirical test of three forest types in British Columbia and Alberta. Can. J. For. Res. 33: 1227-1237.

Chen, S. 1997. Interpreting main effects when a two-way interaction is present. B.C. Min. For., Victoria, B.C. Biometrics Information Pamphlet No. 57, 8 p.

Claveau, Y., C. Messier and P.G. Comeau. 2005. Interacting influence of light and size on above ground biomass distribution in sub-boreal conifer saplings with contrasting shade tolerance. Tree Physiology 25: 373-384.

Claveau, Y., P.G. Comeau, C. Messier and K.D. Coates. 2002. Growth and crown morphological responses of boreal conifer seedlings and saplings with contrasting shade tolerance to a gradient of light and height. Can. J. For. Res 32: $458-468$.

Coates, K.D. 2000. Conifer seedling response to northern temperate forest gaps. For. Ecol. Manage. 127: 249-269.

Coates K.D. and P.J. Burton. 1999. Growth of planted tree seedlings in response to ambient light levels in northwestern interior cedar-hemlock forests of British Columbia. Can. J. For. Res. 29: 1374-1382.

Comeau, P.G. 2014. Effects of aerial strip spraying onmixedwood stand structure and tree growth. Forest. Chron. 90(4): 479-485.

Comeau, P.G., B.S. Biring and G.J. Harper. 1999. Conifer response to brushing treatments: A summary of British Columbia data. B.C. Min. For., Res. Br., Victoria, B.C. Exten. Note 41. Available from: https://www.for.gov.bc.ca/hfd/pubs/ Docs/En/En41.htm

Comeau, P.G., J.L. Heineman and T. Newsome. 2006. Evaluation of relationships between understorey light and aspen basal area in the British Columbia central interior. For. Ecol. Manage. 226: 80-87.

Cornell, J.A. and R.D. Berger. 1987. Factors that influence the value of the coefficient of determination in simple linear and nonlinear regression models. Phytopathology 77: 63-70. Cortini, F., P.G. Comeau, J.O. Boateng and L. Bedford. 2010. Yield implications of site preparation treatments for lodgepole pine and white spruce in northern British Columbia. Forests 1: 25-48.

Dampier J.E.E., F.W. Bell, M. St-Amour, D.G. Pitt and N.J. Luckai. 2006. Cutting versus herbicides: Tenth-year volume and release cost-effectiveness of sub-boreal conifer plantations. Forest. Chron. 82 (4): 521-528.
DeLong, C.S. 2007. Relative impact of aspen competition and soil factors on the performance of lodgepole pine and hybrid white spruce in north-central British Columbia. B.C. Min. For. Range, Res. Br., Victoria, B.C. Tech. Rep. 039.

DeLong, C. and D. Tanner. 1996. Effect of aspen competition on survival and growth of lodgepole pine and white spruce. In: Ecology and Management of B.C. Hardwoods. Workshop Proceedings December 1 and 2, 1993, Richmond, B.C. Edited by Comeau, P.G., G.J. Harper, M.E. Blache, J.O. Boateng and K.D. Thomas. FRDA Report No. 255. B.C. Ministry of Forests, Victoria, B.C. 246 p.

Demaerschalk, J.P. and A. Kozak. 1974. Suggestions and criteria for more effective regression sampling. Can. J. For. Res. 4: 341-348.

Dhar, A., J.R. Wang and C.D.B. Hawkins. 2015. Interaction of trembling aspen and lodgepole pine in a young sub-boreal mixedwood stand in central British Columbia. Open Journal of Forestry 5: 129-138.

Filipescu, C.N. and P.G. Comeau. 2007. Competitive interactions between aspen and white spruce vary with stand age in boreal mixedwoods. For. Ecol. Manage. 247: 175-184.

Forrester, D.I. 2014. The spatial and temporal dynamics of species interactions in mixed-species forests: From pattern to process. For. Ecol. Manage. 312: 282-292.

Frey, B.R., V.J. Lieffers, S.M. Landhausser, P.G. Comeau and K.J. Greenway. 2003. An analysis of sucker regeneration of trembling aspen. Can. J. For. Res. 33: 1169-1179.

Groot, A., S. Adhikary, M. Sharma, N. Luckai, F.W. Bell and G.R. Larocque. 2014. Effect of species composition on the production rate and efficiency of young Picea glauca-Populus tremuloides forests. For. Ecol. Manage. 315: 1-11.

Harper, G and J. Roach. 2014. The role of broadleaf trees: impacts of managing boreal and sub-boreal mixedwood forests in British Columbia. Victoria, B.C. Exten. Note 110. Available from: https://www.for.gov.bc.ca/hfd/pubs/Docs/en/ EN110.pdf

Harper, G., K. Polsson and J. Goudie. 2008. Modelling vegetation management treatments with the Tree and Stand Simulator. Forest. Chron. 84(1): 53-59.

Harper, G.J., M. O'Neill, P. Fielder, T. Newsome and C. Delong 2009. Lodgepole pine growth as a function of competition and canopy light environment within aspen dominated mixedwoods of central interior British Columbia. For. Ecol. Manag. 257: 1829-1838.

Heineman, J.L., D.L. Sachs, S.W. Simard and W.J. Mather. 2010. Climate and site characteristics affect juvenile trembling aspen development in conifer plantations across southern British Columbia. For. Ecol. Manage. 260: 1975-1984.

Kelty, M.J. 1992. Comparative productivity of monocultures and mixed-species stands. In The ecology and silviculture of mixed-species forests. Edited by M.J. Kelty, B.C. Larson and C.D. Oliver. 1992. Kluwer Academic Publishers pp. 125-141. Kenkel, N.C. 1994. Bivariate pattern analysis of jack pine trembling aspen interaction. Abstracta Botanica 18 (2): 49-55.

Kljun, N., T.A. Black, T.J. Griffis, A.J. Barr, D. GaumontGuay, K. Morgenstern, J.H. McCaughey and Z. Nesic. 2006. Response of net ecosystem productivity of three boreal forest stands to drought. Ecosystems 9: 1128-1144. 
Kobe, R.K. and K.D. Coates. 1997. Models of sapling mortality as a function of growth to characterize interspecific variation in shade tolerance of eight tree species of northwestern British Columbia. Can. J. For. Res. 27: 227-236.

Kozak, A. 1988. A variable-exponent taper equation. Can. J. For. Res. 18: 1363-1368.

Landhausser, S.M. and V.J. Lieffers. 2001. Photosynthesis and carbon allocation of six boreal tree species grown in understory and open conditions. Tree Physiol. 21: 243-250.

Lange, J., K. Menounos and C. Hawkins. 2004. Sustainable mixedwood management, growth and yield and wood quality in SBS mixedwood stands. FII contract number: R04-093. Technical Report. University of Northern British Columbia. Prince George, B.C.

Larson, B.C. 1992. Pathways of development in mixedspecies stands. In The ecology and silviculture of mixedspecies forests. Edited by M.J. Kelty, B.C. Larson and C.D. Oliver. 1992. Kluwer Academic Publishers. pp. 3-26.

Lieffers, V.J., G.W. Armstrong, K.J. Stadt, and E.H. Marenholtz. 2008. Forest regeneration standards: Are they limiting management options for Alberta's boreal mixedwoods? Forest. Chron. 84:76-82.

Lieffers, V.J., C. Messier, K.J. Stadt, F. Gendron and P.G. Comeau. 1999. Predicting and managing light in the understory of boreal forests. Can. J. For. Res. 29: 796-811.

MacIsaac, D.A. and S. Navratil. 1996. Competition dynamics in juvenile boreal hardwood-conifer mixtures. In: Comeau, P.G. and K.D. Thomas (ed.). Silviculture of temperate and boreal broadleaf-conifer mixtures. 1996. Land Management Handbook 36. B.C. Min. For., Victoria, B.C.

Mason, W.L. and T.Connolly. 2014. Mixtures with spruce species can be more productive than monocultures: Evidence from the Gisburn experiment in Britain. Forestry 87: 209-217.

McCulloch, L. and R. Kabzems. 2009. British Columbia’s northeastern forests: Aspen complex stand establishment decision aid. BC J. Ecosyst. Manag. 10 (2): 51-58.

McKinnon, L.M. and G.J. Kayahara. 2003. Ecology and management of microclimate in boreal mixedwoods. Northeast Science and Information, Ont. Min. Natural Resour., South Porcupine, Ont. Boreal Mixedwood Notes 28. 13 p.

Meidinger, D. and J. Pojar. 1991. Ecosystems of British Columbia. B.C. Min. For., Res. Br., Victoria, B.C. Spec. Rep. Ser. 6. Available from: https://www.for.gov.bc.ca/hfd/pubs/ docs/srs/Srs06.pdf

Miller, J.H., B.R. Zutter, S.M. Zedaker, M.B. Edwards and R.A. Newbold. 2003. Growth and yield relative to competition for loblolly pine plantations to midrotation-A southern United States regional study. South J. Appl. For. 27(4): 237-252.

Mitchell, K.J., M. Stone, S.E. Grout, C.M. Di Lucca, G.D. Nigh, J.W. Goudie, J.N. Stone, A.J. Nussbaum, A. Yanchuk, S. Stearns-Smith and R. Brockley. 2004. TIPSY V4.2. http://www.for.gov.bc.ca/hre/software/

Navratil, S., P. Phillips and R. Morton. 1990. Aspen competition and lodgepole pine growth in mixed regeneration in western Alberta. In: Vegetation management: An integrated approach. Proceedings of the fourth annual vegetation management workshop. E. Hamilton (compiler), FRDA Report 109.

Neter, J., W. Wasserman and M.H. Kutner. 1990. Applied linear statistical models: Regression, analysis of variance, and experimental designs. $3^{\text {rd }}$ ed. Irwin, Inc.
Newsome, T. 1997. Assessing the effects of aspen competition on lodgepole pine growth. Extension Note \# 20. Research Section, Ministry of Forests, Cariboo Forest Region, Williams Lake, B.C.

Newsome, T. 1999. Assessing the effects of aspen competition on lodgepole pine growth in the IDF $\mathrm{dk} 3 \& 4$. Extension Note \# 27. Research Section, Ministry of Forests, Cariboo Forest Region, Williams Lake, B.C.

Newsome, T.A., J.L. Heineman and A.F.L. Nemec. 2003. Competitive effects of trembling aspen on lodgepole pine performance in the SBS and IDF zones of the CaribooChilcotin region of south-central British Columbia. B.C. Min. For., Res. Br., Victoria, B.C. Tech. Rep. 005.

Newsome, T.A., J.L. Heineman and A.F.L. Nemec. 2004. Lodgepole pine response to aspen removal in variable radii in the SBSdw2 variant near Williams Lake, B.C. B.C. Min. For., Res. Br., Victoria, B.C. Tech. Rep. 014.

Newsome, T.A., J.L. Heineman and A.F.L. Nemec. 2006a. Effects of variable aspen retention on stand development, aspen sucker production, and growth of lodgepole pine in the SBSdw1 variant of south-central British Columbia. B.C. Min. For. Range, Res. Br., Victoria, B.C. Tech. Rep. 032.

Newsome, T.A., J.L. Heineman and A.F.L. Nemec. 2006 b. Early effects of manipulating aspen density and spatial arrangement on lodgepole pine performance, aspen sucker production, and stand development in an 11-year-old stand in the SBPSxc subzone of south-central British Columbia. B.C. Min. For., Res. Br., Victoria, B.C. Tech. Rep. 029.

Newsome, T.A., J.L. Heineman and A.F.L. Nemec. 2008. Competitive interactions between juvenile trembling aspen and lodgepole pine: A comparison of two interior British Columbia ecosystems. For. Ecol. Manag. 255: 2950-2962.

Newsome, T.A., J.L. Heineman and A.F.L. Nemec. 2010. A comparison of lodgepole pine responses to varying levels of trembling aspen removal in two dry south-central British Columbia ecosystems. For. Ecol. Manag. 259: 1170-1180.

Peterson, E.B. and N.M. Peterson. 1995. Aspen manager's handbook for British Columbia. FRDA Report No. 230. B.C. Ministry of Forests, Victoria, B.C. 110 p. Available from: https://www.for.gov.bc.ca/hfd/pubs/docs/Frr/Frr230.pdf

Prasad, R. 2002. Conifer release of lodgepole pine (Pinus contorta) following treatment of aspens with a bioherbicide agent (Chrondrostereum purpureum) in British Columbia, Canada. In: Poplar summaries from the fourth international conference on forest vegetation management. Nancy, France. June 17-21, 2002. Compiled by Frochot, H., C. Collet and P. Balandier. pp. 109-111.

Pretzsch, H. 2009. Forest dynamics, growth and yield: From measurements to model. Chapter 9, pp. 337-380. pp. SpringerVerlag Berlin Heidelberg. 664 p. Available from: http:// www.crc.uqam.ca/Publication/Forest $\% 20$ Dynamics, $\% 20$ Gro wth\%20and\%20Yield.pdf

Radosevich, S.R. and K. Osteryoung. 1987. Principles governing plant-environment interactions. Chapter 5. In: Walstad, J.D. and P.J. Kuch. 1987. Forest vegetation management for conifer production. John Wiley and Sons, New York. 523 p. SAS Institute Inc., 2010. SAS OnlineDoc ${ }^{\circledR}$ 9.3., Cary, NC: SAS Institute Inc.

Sheldan, T. and J. Snetsinger. 2008. Memorandum: Incorporation of mixedwood and broadleaves into Forest Stewardship Plan stocking standards, SP amendments and TSR regeneration assumptions. B.C. Min. For. and Range, Victo- 
ria, B.C. Available from: http://www.for.gov.bc.ca/hfp/silviculture/111624\%20signed\%20CF\%20broadleaf\%20Memo.pdf Simard, S.W., J.L. Heineman, W.J. Mather, D.L. Sachs and A. Vyse. 2001. Effects of operational brushing on conifers and plant communities in the southern interior of British Columbia: Results from PROBE 1991-2000. B.C. Min. For., Victoria, B.C. pp. 312-240. Land Management Handbook 48. Available from https://www.for.gov.bc.ca/hfd/pubs/docs/ $\mathrm{Lmh} / \mathrm{Lmh} 48 . \mathrm{htm}$

Simard, S.W., S.M. Hagerman, D.L. Sachs, J.L. Heineman and W.J. Mather. 2005. Conifer growth, Armillaria ostoyae root disease, and plant diversity responses to broadleaf competition reduction in mixed forests of southern interior British Columbia. Can. J. For. Res. 35: 843-859.

Sit, V. and M. Poulin-Costello. 1994. Catalog of curves for curve fitting. Biometrics information handbook series. Handbook No. 4. March 1994. Res. Br., B.C. Min. For., Victoria, B.C. Available from: http://www.for.gov.bc.ca/hfd/pubs/ Docs/Bio/Bio04.htm

Smith, D.M. 1986. The Practices of Silviculture. $8^{\text {th }}$ edition. John Wiley and Sons, New York. 527 p.

South, D.B. and J.H. Miller. 2007. Growth response analysis after early control of woody competition for 14 loblolly pine plantations in the southern U.S. For. Ecol. Manage. 242: 569-577.

St. Clair, S.B., X. Cavard and Y. Bergeron. 2013. The role of facilitation and competition in the development and resilience of aspen forests. For. Ecol. Manage. 299: 91-99.

Strong, W.L. and S.S. Sidhu. 2005. Prolonged herbicideinduced vegetation changes in a regenerating boreal aspen clearcut. J. Environ. Manag. 77: 194-204.

Temesgen, H. and K.V. Gadow. 2004. Generalized height-diameter models-an application for major tree species in complex stands of interior British Columbia. Eur. J. Forest Res. 123: 45-51.

Yang, RC, A. Kozak and J.H.G. Smith. 1978. The potential of Weibull-type functions as flexible growth curves. Can. J. For. Res. 8: 424-431.
Yao, X., S.J. Titus and S.E. MacDonald. 2001. A generalized logistic model of individual tree mortality for aspen, white spruce, and lodgepole pine in Alberta mixedwood forests. Can. J. For. Res. 31: 283-291.

Voicu, M.F. and P.G. Comeau. 2006. Microclimate and spruce growth gradients adjacent to young aspen stands. For. Ecol. Manage. 221: 13-26.

Wagner, R.G., 2000. Competition and critical-period thresholds for vegetation management decisions in young conifer stands. Forest. Chron. 76: 961-968.

Walmsley, M., G. Utzig, T. Vold, D. Moon and J. van Barneveld. 1980. Describing ecosystems in the field. RAB technical paper 2. Land Management Report No. 7. Province of B.C., Victoria, B.C. Available from: http://www.llbc.leg.bc.ca/ public/PubDocs/bcdocs/264741/Lmr007.pdf

Walstad, J.D. and P.J. Kuch. 1987. Forest Vegetation Management for Conifer Production. John Wiley and Sons, New York. 523 p.

Williams H., C. Messier and D.D. Kneeshaw. 1999. Effects of light availability and sapling size on the growth and crown morphology of understory Douglas-fir and lodgepole pine. Can. J. For. Res. 29: 222-231.

Wright E.F., K.D. Coates, C.D. Canham and P. Bartemucci. 1998. Species variability in growth response to light across climatic regions in northwestern British Columbia. Can. J. For. Res. 28: 871-886.

Zhang, Y., H.Y.H. Chen and P.B. Reich. 2012. Forest productivity increases with evenness, species richness and trait variation: a global meta-analysis. J. Ecol. 100: 742-749.

Zhao, D., B. Borders and M. Wilson. 2004. Individual-tree diameter growth and mortality models for bottomland mixed-species hardwood stands in the lower Mississippi alluvial valley. For. Ecol. Manage. 199: 307-322. 